Community Inclusion as A Mechanism to Reduce The Social Exclusion of Children With Motor Disabilities

BY

Dr. Zainhom Mashhot Sayed Ahmed Khawaga Assistant Professor of Social Planning - Faculty of Social Work - Helwan University Dr. Asmaa Adel Mohamed Selim Assistant Professor of social planning - Faculty of Social Work - Helwan University 
مجلة كلية الخدمة الاجتماعية للار اسات و البحوث الاجتماعية - جامعة الفيوم 
مجلة كلية الخدمة الاجتماعية للار اسات و البحوث الاجتماعية - جامعة الفيوم

\section{Community Inclusion as A Mechanism to Reduce The Social Exclusion of Children With Motor Disabilities}

\section{Summary:}

The study aimed to decide the degree of Community Inclusion measurements, and to decide the degree of the elements of restricting the social prohibition of orphan children with motor disabilities, and to decide the challenges confronting social reconciliation to lessen social exclusion of children with motor disabilities, to reach proposed systems to actuate social incorporation to diminish the social exclusion of children with motor disabilities orphans.

This study is viewed as a field study, using the social survey method. The research population was : all the children with portability disabilities for orphans at the Sondos Foundation for Orphans with Special Needs and their number (90), and all the authorities at the Sondos Foundation for Orphans with Special Needs and its branches and their number (52). The study tools consisted of a interview form for orphan children with mobility impairments and a questionnaire form for officials.

From the main study finding : there was a factually noteworthy direct impact connection between cultural incorporation and the decrease of social prohibition for children with motor disabilities.

Key words:

Community Inclusion - Social Exclusion - Motor disability - Children With Motor Disabilities 


\section{الدمج المتهمعي كآلية للهد هن الاستبعاد الاجتهماعي للأطفال الأيتام المعاقين}

\section{حركيًا}

الملخص

استهدفت الدراسة تحديد مستوى أبعاد الدمج المجتمي، وتحديد مستوى أبعاد الحد من الاستبعاد الاجتماعي للأطفال الأيتام المعاقين حركياً، وتحديد الصعوبات التي تواجه الدمج المجتمي للحد من الاستبعاد الاجتماعي للأطفال الأيتام المعاقين حركياً، وصولاً إلى آليات مقترحة لتفعيل الدمج المجتمي للحد من الاستبعاد الاجتماعي للأطفال الأيتام المعاقين حركياً. وتعد هذه الدراسة من الدراسات الوصفية، واعتمدت الدراسة على المنهج العلمي باستخدام منهج المسـح الاجتمـاعي الثـامل للأطفـال الأيتـام المعـاقين حركيـاً بمؤسسـة السـندس للأيتـام ذوي الاحتياجـات الخاصـة وفروعها وعددهم (90) مفردة، وكذلك منهج المسـح الاجتمـاعي الثـامل للمسئولين بمؤسسة السندس للأطفال الأيتام ذوي الاحتياجات الخاصـة وفروعها وعددهم (52) مفردة.

وتمثلت أدوات الدراسـة في استمارة استبار للأطفال الأيتام المعـاقين حركيـاً واستمارة استبيان للمسئولين. وتوصلت نتائج الدراسـة إلى وجود علاقـة طرديـة تأثيريـة دالـة إحصـائياً بين الدمج المجتمعي والحد من الاستبعاد الاجتماعي للأطفال الأيتام المعاقين حركياً. الكلمات المفتاحية: الدمج المجتمي، الاستبعاد الاجتماعي، الإعاقة الحركية، الأطفال الأيتام المعاقين حركياً 


\section{First: The Study Problem:}

Childhood is the principal phase of life and its initial move towards combination and sublimation and it is a significant fundamental stage in preparing and assessment where the child is arranged and restored (Bawadi, 2005, p. 7), and handicap has become a difficult that worries an enormous area of specialists in all fields since it is a social wonder as much There is a ton of spread in all social orders, which requires gigantic endeavors to give the fundamental administrations to these children, with the goal that the handicapped child doesn't turn into a weight on his family and society and afterward on the express that would deal with people, particularly since the level of the debilitated is expanding, which speaks to a risk to society (Hassan, 2002, p. 164).

The scientists bring up the significance of the child's essence in the family regardless of whether the family circumstance isn't proper, it is superior to quality in whatever other organization, where the child comes up short on the human connections that the family air gives, since care in the foundation can not supplant a sound family life (Melegy, 2003, P. 30), and if hardship of families establishes a mental and social weight on children and prompts introduction to numerous issues and weights for solid children denied of family care, and for children who experience the ill effects of inability, the issue turns out to be more extreme and more terrible, particularly as handicap in itself comprises Problem.

Muhammad study (2006) indicated that orphan children experience the ill effects of the issue of helpless social relations, instructive issues, powerless social investment and connection. As the issue of inability is a significant issue, in any general public and prompts blocking the procedure of improvement and progress in it, and the markers of development and the headway of countries are spoken to in the degree of their consideration to instruct ages of all age gatherings, center, consideration and care for the impaired, and give chances to far reaching development for them, which sets them up to take part in the public arena besides Caring for the debilitated is a philanthropic rule that asserts the privileges of these impeded individuals and attempts to furnish them with suitable chances so they can coordinate with other typical individuals.

The idea of coordinating the incapacitated is a moderately late idea, as it developed in 1981 through the trademark of the International Year of Disabled, equity and full investment, just as through the idea of a general public for all, and the worldwide statement of instruction for all finished in featuring the quality of this stage, and joining in the jewel of a moral social idea coming from Human rights, and combination is legitimately founded on a social viewpoint is that the crippled are a piece of the texture of the general public wherein they live and can't be isolated from 
their locale (Imam, 2002, p. 26), where the incorporation procedure gives the arrangement of social government assistance projects, for example, trips, camps, gatherings and clinical consideration, for example, medical coverage. Helping the child to accommodate with others, recreational and donning care, physical wellness, motor abilities, team activities programs, instructive and social consideration (Abu Al-Nasr, 2004, p. 136), and this was affirmed by an study(Abu Zaid, 2012) where I reasoned that the most significant needs of the disabled individuals are found in foundations Orphan care is the social needs, including the development of social relations with his associates in the establishment, the requirement for confidence, and the requirement for information and entertainment.

Subsequently, orphan children speak to a significant gathering in the public arena, so society thinks about this gathering, and intrigue shows up through getting ready foundations that serve them (Muhammad, 2002, p. 27). One of the significant models in the public eye is that thinking about stranded children with portability is one of the significant rules in the public eye, on the grounds that the issue of the handicapped is one of the human rights issues affirmed by universal associations and remembered for the nation's constitutions. All his organic, mental, mental and social needs, and This was affirmed by a study(Matthe, 2005) that arrived at That it is critical that both the education and child welfare systems work to identify problems early in a child's educational career. Furthermore, interventions must address not just the problematic behaviors but also the core problems underlying these children's behavioral issues.

This was affirmed by a study of Hamzah (2003), where the study showed that the most significant arranging pointers to confront the obstructions to incorporating the crippled as a rule instruction schools were: working with the family, the disabled, and society as an incorporated social facilitator, and a system was created to work with the impeded from a social assistance viewpoint. This procedure is spoken to in Relying on investment and chipping in work with the handicapped, and concentrating on the collaboration, and it is the premise in working with the crippled.

In like manner, social inclusion comprises of projects that expect to contribute the accessible natural assets and abilities to stand up to the issues emerging from not fulfilling the person's organic, mental and social needs or altering the accessible assets and growing new assets that lead to the necessary fulfillment (Darwish, Masoud, 2009, p. 259), and from here The incorporation of socially impeded individuals, particularly the genuinely incapacitated, has an exceptionally positive effect on them, their families, and society, which requires more endeavors to actuate the job of organizations during the time spent social reconciliation of the disabled with the common, and there are numerous types of mix 
including (aggregate or "thorough" combination, incomplete mix, Spatial joining, social coordination, utilitarian mix, and community integration), and the standards of the procedure of mix rehearsed by Egypt depend on the rule of the option to rise to circumstances, and the guideline of the option to partake in the life of society, through the type of community integration, and the chance to take an interest in all exercises in the community by the debilitated (Hamza, 2003, p. 45).

This is in accordance with the consequences of the study(Hammam, 2016) that stressed the requirement for persistent assessment of the procedure of community joining for the incapacitated to know the weaknesses of the answer for work and the qualities to help them, just as the arrangement of particular preparing programs at all levels inside every establishment identified with social consideration, just as the utilization of broad communications widely To urge society to collaborate and furnish all offices that permit people with disabilities to coordinate into society with the standard in training and work with no segregation.

The consequences of the Imaniah \& Fitria study (2018) additionally affirmed that Adequate infrastructure also needs to be given to the school that organizes inclusive education for an efficient and effective students understanding learning-oriented of inclusive education. In short, every child has the same opportunity in education, yet for special education which is aimed at student with special educational needs.

The after effects of the (Place; Hodge, 2001) concentrate additionally found that students with and without disabilities infrequently engaged in social interactions.

This was affirmed by an study(Fahmy, 2006), which reasoned that the experience of coordination in Egypt despite everything requires a great deal of audit and exploration study to discover what forestalls the accomplishment of its objectives.

This underscores the significance of accomplishing community consideration for orphans with disabilities so as to decrease their social prohibition in elective consideration establishments. Since social avoidance is something contrary to mix (Al-Jawhary, 2008, p. 10).

Different components of social exclusion influence each other, thus creating a spiral of insecurity, which ends in multiple deprivation. Deprivation usually begins with the loss of employment, which in turn leads to a significant degradation in living standards, that is, increased risk of poverty. Living in poverty creates additional difficulties in the search for employment and contributes to a long-term unemployment trap for many individuals. At the same time, unemployment and poverty inhibit participation in social activities. Due to the lack of money and to the stigmatisation that can be caused by unemployment, social ties are 
weakened, increasing the probability of social isolation. If the period of unemployment, and consequently poverty, is prolonged, tensions will occur in the family and in marital relations. In other words, the disintegration of marriage and family becomes more likely. The lack of money worsens not only family relations but also ties with friends, neighbours, and relatives, since 'social exchange' is necessary for the maintenance of social relations. In turn, the social isolation has an adverse effect on employment, since the individuals concerned are isolated from sources of information and lack the support needed for employment search (UNDP, 2006, P 12).

This is affirmed by the study(Al-Rashidi, 2009), where it reasoned that the incapacitated need prosthetic gadgets in light of the fact that their absence of them makes them unfit to coordinate into society, however from the beneficial side, they have to furnish openings for work proportionate with their capacities so they don't feel social prohibition As for political cooperation, they have to connect the disabled to his general public's political and financial issues so they don't feel social avoidance, and that they have to empower them and their feeling of self-assurance, build up an awareness of others expectations, and lessen repressed emotions in itself.

Prohibition is connected to the rejection of certain people, families, or gatherings, in entire or to some degree, from taking an interest in the open life in which they live or partaking in settling on choices that influence their lives.

This is affirmed by the Ashour \& Fraija study 2019). Therefore, the social exclusion does not concern only poor people nor political position or a social class. It $\mathrm{s}$ everyone's problem. If any country make efforts for the sake the different areas of development or bridging the gap between social classes for the purpose of narrawing teh circle of the social exclusion, which supposed to be only indicator that measures the success or the failure of any development project which is sponsored by the State Department in this area.

While the consequences of the Clarke study(2006) demonstrate that Whilst disabled children and their families may face specific barriers to social participation and inclusion, the needs of disabled children are often the same as the needs of other children. and Tackling exclusion of disabled children and their families includes but is not restricted to ensuring inclusion in public spaces. And Inclusion needs to be considered with clear reference to children's key relationships.

Exclusion consists of dynamic, multidimensional processes driven by unequal power relationships interacting across four main dimensions economic, political, social and cultural - and at different levels including 
individual, household, group, community, country and global levels. The characteristics of the four main dimensions in: (WHO, 2010, p 7).

1. The social dimension is constituted by proximal relationships of support and solidarity (such as friendship, kinship, family, neighbourhood, community, social movements) that generate a sense of belonging within social systems. Social bonds are strengthened or weakened along this dimension.

2. The political dimension is constituted by power dynamics in relationships which generate unequal patterns of formal rights embedded in legislation, constitutions, policies and practices and the conditions in which rights are exercised, including access to safe water, sanitation, shelter, transport and power and to services such as health care, education and social protection. Along this dimension, there is an unequal distribution of opportunities to participate in public life, to express desires and interests, to have interests taken into account and to have access to services.

3. The cultural dimension is constituted by the extent to which diverse values, norms and ways of living are accepted and respected. Diversity is accepted in all its richness at one extreme along this dimension, and at the other there are extreme situations of stigma and discrimination.

4. The economic dimension is constituted by access to, and distribution of, material resources necessary to sustain life (such as income, employment, housing, land, working conditions and livelihoods).

This is predictable with the consequences of an study(Gijsbers and Vrooman, 2012) that affirmed that social exclusion has been conceptualised as a state of individuals in relation to four dimensions. Two of these dimensions - material deprivation and social rights - are of a structural nature. The other two - social participation and normative integration - pertain to social settings and subcultural factors. Theoretically and empirically, the dimensions refer to one latent underlying social exclusion variable.

It is likewise steady with the after effects of Postrzygacz \& et, al, study (2019) that affirmed that it needs to be pointed out that growing inequalities result from unequal (often unfair distribution of financial resources and reflect in integration and inclusion barriers and also their results as social problems which again have its source in exclusion (often interchangeably named as a social exclusion.

Along these lines, social work by and large and social Planning specifically should concentrate on taking care of cultural issues, using every single proficient strategy and potential outcomes, taking into account that social arranging is an intentional and reasonable procedure 
where the individual, gathering, and society take part (diabetes, 2000, p. 378 ) to diminish the social exclusion of children Physically disabled vagrants, since it is a significant issue that affects the advancement of society, and furthermore in light of the fact that children with portability orphans are in critical need of community incorporation and lessen their social avoidance.

Enabling the objective gatherings so as to acquire benefits and coordinating plans, projects and activities towards the overall cultural objectives so as to accomplish fairness, vote based system and social equity, as it is viewed as a significant pivot to stand up to the issue of neediness through a lot of explicit methodologies for legislative and common endeavors and standards guided at social work in the public eye to accomplish Social equity, equity, standardized savings, and coordinating logical plans connecting the monetary, political, ideological, and esteem structure in the public arena (Al-Suruji, 2004, p. 16).

Therefore Social Planning as a logical strategy adds to tending to the issues and issues confronting the person specifically and society when all is said in done, among which is the issue of social consideration and the issue of social exclusion of children with portability disabilities, through characterizing long haul vital objectives and attracting social consideration arrangements to be accomplished later on and structuring projects and ventures Within the system of time intends to stay up with future desires.

Based on the previous, social prohibition is something contrary to social incorporation. Social exclusion in its signs of prohibition, segregation, hardship or absence of strengthening places people, families or gatherings in a circumstance in which they allude to social disengagement, estrangement, and abuse, and may add up to brutality. This requires the need of accomplishing social combination for these gatherings, particularly the powerless and underestimated gatherings, incorporating stranded children with inabilities.

In the light of the previous, the debilitated orphan children with portability experience the ill effects of numerous issues and weights, and there are elective consideration organizations important to them, including the Al-Sondos Foundation for Handicapped Orphan Children in Cairo Governorate, and the current study will concentrate on the social mix of the stranded children with disabilities to decrease their social prohibition, Based on the above mentioned, the study issue is resolved in a lot of the accompanying sub-issues:

1. What is the truth of cultural incorporation of crippled stranded children? 
2. What is the truth of the components of social exclusion of children with physical inabilities?

3. What is the degree of the connection between cultural incorporation and social prohibition of children with physical inabilities?

4. What are the troubles blocking the accomplishment of community integration to decrease the social exclusion of children with disabilities in vagrants?

5. What is the proposition to actuate Community Inclusion to decrease the social exclusion of children with physical disabilities?

\section{Second: The Study Goals:}

1. Determining the degree of the social incorporation measurements of incapacitated stranded children.

2. Determining the degree of the elements of restricting the social exclusion of children with physical disabilities.

3. Determining the challenges confronting community joining to decrease the social exclusion of children with disabilities moving.

4. Determining the recommendations to actuate community integration to diminish the social prohibition of children with disabilities.

5. Introducing a proposed components to initiate Community Inclusion to diminish the social prohibition of children with versatility inabilities.

\section{Third: The Importance of the Study:}

1. Community enthusiasm right now with the incapacitated class by helping them to play out their jobs inside the community by incorporating them socially.

2. A truly impaired child is viewed as an idle human vitality inside the community in the event that he doesn't get proper consideration and restoration.

3. Community reconciliation is the reason for constraining the social prohibition of children with motor disabilities, all together for these children to appreciate equity with the conventional.

4. Focusing Social welfare policies on accomplishing social incorporation for helpless and minimized gatherings, just as confronting social prohibition of these gatherings to improve the nature of their lives.

5. Attention of Social welfare policies to the needs of social government assistance for all gatherings of society as a rule and for the truly crippled specifically, at each phase of social work in a manner that adds to accomplishing social government assistance for citizenry. 
6. The calling of social Work when all is said in done, and social Planning specifically, add to accomplishing social advancement in all fields, including accomplishing community coordination for children with portability disabilities.

\section{Fourth: The Study Hypotheses:}

(1) The first main hypothesis of the study: "It is expected that the level of societal dimensions of integration of children with motor disabilities orphans is average":

This hypothesis can be tested through the following dimensions:

1. Availability of human relations.

2. Make a change in the behavior of orphans with disabilities in motion.

3. Continuity in achieving social inclusion.

4. Provide a system for following up with disabled orphaned children.

(2) The second main hypothesis of the study: "It is expected that the level of dimensions of limiting the social exclusion of children with motor disabilities orphans is moderate":

This hypothesis can be tested through the following dimensions:

1. Non-social isolation.

2. No social deprivation.

3. Non-discrimination.

4. Social interaction.

(3) The third main hypothesis of the study: "There is a statistically significant direct effect relationship between societal inclusion and the reduction of social exclusion of children with mobility orphans."

(4) The fourth main hypothesis of the study: "There are statistically significant differences statistically between the responses of the orphaned children with mobility impairment and the officials with regard to their determination of the level of dimensions of societal inclusion of the orphaned children with mobility disabilities."

(5) The fifth main hypothesis of the study: "There are statistically significant differences between the responses of the orphaned children with mobility impairments and the officials with regard to their determination of the level of the dimensions of limiting the social exclusion of the orphans with disabilities."

\section{Fifth: Study Concepts:}

\section{(1) Community Inclusion:}

The emphasis on " inclusion " in the Sustainable Development Goals (SDGs) compels us to specify what social inclusion is and how to accomplish it. The Open Working Group's 2030 Sustainable Development. in Goal 10 to "empower and promote the social, economic and political inclusion of all, irrespective of age, sex, disability, race, 
ethnicity, origin, religion or economic or other status"; This insistence on promoting social inclusion calls for a more precise understanding of what this entails (Silver. 2015. P1).

Community Inclusion is characterized as contributing the energies and capacities of people with disabilities in accomplishing their social adjustment and reinforcing social relations, furnishing them with wanted social qualities and social aptitudes and helping them to have an ordinary existence and adjust to individuals from the nearby community (Saleh, 2003, p. 121).

community incorporation is additionally characterized as accomplishing a more significant level in the exhibition of social jobs for people with physical or mental disabilities by taking an interest in social and recreational exercises, and by partaking in social clubs and different associations of their own (Suleiman, 2004, p. 193).

community coordination implies furnishing open doors for people with disabilities to incorporate into the different exercises of society to become dynamic individuals who reserve the option to work, move around and appreciate all the accessible administrations in the general public where they live (Turki, 2015, p. 5).

Inclusion as equality was presented, then, as a new space of politic and possibilities, an opportunity perhaps to create a democratic or even subversive world which offered the chance for disability and equality to be located within a new cultural framework (Hodkinson, 2011, P 180).

The idea of cultural incorporation in this study demonstrates that the crippled stranded children with portability are allowed the chance to partake with their ordinary friends in all parts of life to change their negative perspectives towards society, offer a wide range of assistance and exercises to them, and furnish them with social aptitudes so as to have a typical existence, by giving human relations and making change In the conduct of orphans with disabilities moving and accomplishing progression in accomplishing social reconciliation, and giving a framework to catching up on orphans with disabilities moving.

\section{(2) Social exclusion:}

The Term social prohibition is utilized to depict what happens when individuals are barred from fundamental administrations, and that avoidance centers around specific gatherings in the public eye reserve the option to approach openings contrasted with others, which prompts a lower capacity of the person to take an interest in the social, monetary, and political elements of society, and that bunches Socially rejected can be those that are denied every one of their privileges and have no social ties (Abu Al-Nasr, 2012, p. 35). 
The concept of social exclusion refers to its employment as an explanatory tool to understand and analyse the processes that cause poverty and inequality, compared to its use as a descriptive term to describe or label disadvantaged individuals or communities (Arthurson\& Jacobs, 2003).

Social exclusion is often perceived as a vicious circle with three components: unemployment, poverty, and social isolation (UNDP, 2006, P 12).

Social exclusion is a contested term, with dispute over the agency responsible: globalisation, the nation state and its institutions, or excluded individuals themselves. Understanding it involves interactions between influences and outcomes at different levels - individual, family, community, national and global (Hills. et.al, 2014).

The idea of social prohibition in this study alludes to the sentiment of debilitated stranded children with portability, separation, hardship, absence of strengthening, social detachment and the powerlessness to social cooperation with others, which sets them in a place in correlation with others, in this manner abusing their social, monetary and political rights, which requires the need of giving chances to their social joining.

\section{(3) Handicapped orphaned children:}

A child characterizes a orphan as the person who lost his folks and turns into a orphan for guardians, and in these cases he may require insurance from help or government disability frameworks (Badawi, 1987, p. 184).

Concerning the motor incapacity, it implies that there is a deformity in a portion of the organs answerable for the event of this inability, regardless of whether it is bone, anxious, strong or other, and the individual loses the capacities that the body must perform identified with his genuine life exercises, and the explanation might be intrinsic or obtained and he needs clinical and mental mediation Social (Al-Azhari, Abu Hashima, 2010, p. 70).

A physical disability is the long-term loss or impairment of part of a person's body function, resulting in a limitation of physical functioning, mobility, dexterity or stamina. Due to the functional loss the person will experience the inability to perform normal movements of the body, such as walking and mobility, sitting and standing, use of hands and arms, muscle control, etc (Developer Space, 2020, P1).

The idea of motor debilitated orphan children in this study alludes to each child who has lost a dad or mother or both, who is thought about in a consideration establishment for impaired orphan children, and he experiences a physical handicap spoke to by a physical inability in one of his appendages that keeps him from strolling or moving, or sitting or standing, Or the utilization of hands and arms, or control of muscles, and 
he needs mental, well-being and social intercession. He has a condition of defenselessness and physical inadequacies that keeps him from exploiting his capacities like customary individuals.

Sixth: The study Methodology:

This study is viewed as a field study, using the social survey method. The research population was : all the children with portability disabilities for orphans at the Sondos Foundation for Orphans with Special Needs and their number (90), and all the authorities at the Sondos Foundation for Orphans with Special Needs and its branches and their number (52). Also, disperse them as follows:

\section{Table No (1)}

The distribution of the handicapped orphaned children and the Sondos Foundation for orphans with special needs and its branches is illustrated

\begin{tabular}{||l|l|c|c|c|}
\hline \hline$N$ & \multicolumn{1}{|c|}{ Statement } & $\begin{array}{c}\text { The total } \\
\text { number of } \\
\text { disabled } \\
\text { orphans }\end{array}$ & $\begin{array}{c}\text { Number of } \\
\text { physically } \\
\text { disabled } \\
\text { orphaned } \\
\text { children }\end{array}$ & $\begin{array}{c}\text { Number of } \\
\text { officials }\end{array}$ \\
\hline 1 & $\begin{array}{l}\text { Al Sondos House for Handicapped Orphans in Nasr } \\
\text { City (Headquarters) }\end{array}$ & 35 & 22 & 15 \\
\hline 2 & $\begin{array}{l}\text { Dar Al-Firdous for Handicapped Orphans in Nasr } \\
\text { City (Al-Firdous Branch) }\end{array}$ & 32 & 19 & 12 \\
\hline 3 & $\begin{array}{l}\text { Al Sondos House for Handicapped Orphans in Fifth } \\
\text { Settlement (Fifth Settlement Branch) }\end{array}$ & 42 & 24 & 13 \\
\hline 4 & $\begin{array}{l}\text { Al Sondos House for Handicapped Orphans in } \\
\text { Heliopolis (Heliopolis Branch) }\end{array}$ & 42 & 25 & 12 \\
\hline \multicolumn{2}{|c|}{ Total } & 151 & 90 & 52 \\
\hline
\end{tabular}

\section{Seventh: The Study Tools:}

Data collection tools were:

(1) An interview form for children with motor disabilities orphans on community reconciliation to decrease the social rejection of children with motor disabilities:

- The scientists planned a poll for children with motor disabilities, by alluding to the hypothetical legacy, past investigations, and survey structures identified with the subject of the examination.

- The poll depended on the triple chain of importance, so the reaction for each expression is (truly, somewhat, no) and every one of these reactions was given a weight (degree): yes (three degrees), partly (two degrees), nobody (degree) ).

- The specialists depended on coherent genuineness by taking a gander at the writing and hypothetical systems, at that point breaking 
down these writing, exploration and studies so as to arrive at the various measurements identified with the issue of the examination.

- $\quad$ The analysts led the obvious truthfulness of the device subsequent to introducing it to (5) employees at the Faculty of Social Work, Helwan University, and an understanding was affirmed on at least $(80 \%)$, and as needs be the structure was defined in its last structure.

- The analysts additionally directed factual strength for an example of (10) jargon of orphans with disabilities in the study populace utilizing the Alpha-Cronbach research facilities, and its outcomes were as per the following:

Table No (2)

Results of the consistency of the probe form for children with motor disabilities, using the Alpha-Cronbach coefficient $(\mathbf{N}=10)$

\begin{tabular}{|c|l|c|}
\hline $\mathrm{N}$ & \multicolumn{1}{|c|}{ The Dimensions } & $\begin{array}{c}\text { Alpha- } \\
\text { Cronbach } \\
\text { coefficient }\end{array}$ \\
\hline \hline 1 & Dimensions of societal inclusion of children with motor disabilities & $\mathbf{0 . 9 0}$ \\
\hline 2 & Dimensions of reducing the social exclusion of children with motor disabilities & $\mathbf{0 . 8 6}$ \\
\hline 3 & $\begin{array}{l}\text { Difficulties facing community integration to reduce the social exclusion of children } \\
\text { with disabilities }\end{array}$ & $\mathbf{0 . 8 4}$ \\
\hline 4 & $\begin{array}{l}\text { Proposals for activating societal inclusion to reduce the social exclusion of children } \\
\text { with physical disabilities }\end{array}$ & $\mathbf{0 . 8 5}$ \\
\hline \multicolumn{2}{|c|}{ The consistency of the probe form for children with motor disabilities as a whole } & $\mathbf{0 . 8 8}$ \\
\hline
\end{tabular}

Table No (2) shows that:

Most dimensional quickness coefficients are exceptionally steady, so their outcomes can be depended upon and the instrument is in its last structure.

(2) A Questionnaire for authorities on community combination to decrease the social rejection of children with physical disabilities:

- $\quad$ Building a survey for authorities in its underlying structure, in light of the hypothetical system for the past study and studies identified with the subject of the examination, to decide the expressions identified with the elements of the examination.

- The poll structure depended on the triple chain of command, with the goal that the reaction for each expression is (truly, somewhat, no) and every one of these reactions was given a weight (degree): yes (three degrees), to a limited degree (two degrees), nobody (degree).

- $\quad$ The scientists depended on coherent genuineness by taking a gander at the writing and hypothetical systems, at that point examining these writing, study and studies so as to arrive at the various measurements identified with the issue of the investigation. 
- The scientists led the obvious earnestness of the device in the wake of introducing it to (5) employees at the Faculty of Social Work, Helwan University, and an understanding was endorsed on at least $(80 \%)$, and as needs be the structure was detailed in its last structure.

- The scientists additionally directed measurable steadiness for an example comprising of (10) jargon of the study populace utilizing the Alpha-Cronbach research centers, and its outcomes are as per the following:

Table No (3)

Results of the consistency of the officials questionnaire using the Alpha-Cronbach coefficient $(\mathbf{N}=\mathbf{1 0})$

\begin{tabular}{|c|l|c|}
\hline \hline $\mathrm{N}$ & \multicolumn{1}{|c|}{ The Dimensions } & $\begin{array}{c}\text { Alpha- } \\
\text { Cronbach } \\
\text { coefficient }\end{array}$ \\
\hline \hline 1 & Dimensions of societal inclusion of children with motor disabilities & $\mathbf{0 . 8 1}$ \\
\hline 2 & Dimensions of reducing the social exclusion of children with motor disabilities & $\mathbf{0 . 8 7}$ \\
\hline 3 & $\begin{array}{l}\text { Difficulties facing community integration to reduce the social exclusion of children } \\
\text { with disabilities }\end{array}$ & $\mathbf{0 . 8 6}$ \\
\hline 4 & $\begin{array}{l}\text { Proposals for activating societal inclusion to reduce the social exclusion of children } \\
\text { with physical disabilities }\end{array}$ & $\mathbf{0 . 8 9}$ \\
\hline \multicolumn{1}{|c|}{ The consistency of the officials questionnaire as a whole } & $\mathbf{0 . 8 6}$ \\
\hline
\end{tabular}

\section{Eighth: Determining the level of community integration for} orphans with disabilities in motion:

To pass judgment fair and square of cultural incorporation of children with motor hindered vagrants, so the start and end of the triple scale classifications are: yes (three degrees), somewhat (two degrees), nobody (degree), the information is encoded and gone into the PC, and to decide the length of the cells of the triple scale (The upper and lower restricts), the range was determined $=$ the biggest worth - the most reduced worth $(3$ $-1=2$ ), separated by the quantity of cells of the scale to get the amended cell length $(2 / 3=0.67)$ and afterward this worth was included to the least worth the scale or the start of the scale, which is the right one, to decide the maximum furthest reaches of this cell, and accordingly the length of the cells became as follows:

$$
\text { Table No (4) }
$$

Levels of mathematical averages for the dimensions of societal inclusion of children with motor disabilities

\begin{tabular}{|l|c|}
\hline If the average value for the phrase or dimension ranges from 1 to 1.67 & low level \\
\hline If the average value for the phrase or dimension ranges from 1.68 to 2.34 & Medium level \\
\hline If the average value for the phrase or dimension ranges from 2.35 to 3 & High level \\
\hline
\end{tabular}

\section{Ninth: Statistical Analysis Methods:}

The data was collected from (18/1/2020 to 3/26/2020), and explored in the field and office by the researchers, then the data was processed through the computer using the program (SPSS.V. 24.0) statistical 
packages for social sciences, methods were applied The following statistic: frequencies and percentages, mean, standard deviation, range, Spearman-Brown equation for midterm fractionation, simple regression analysis, Pearson correlation coefficient, determination coefficient, T-test for two independent samples, and unidirectional variance analysis.

\section{Tenth: Results of the field study:}

The first axis: the study population description:

(1) Basic data of the orphaned children with mobility impairment of the study population:

Table No (5)

Basic data of children with motor disabilities orphans $(\mathrm{N}=90)$

\begin{tabular}{|c|c|c|c|}
\hline $\mathbf{N}$ & Quantitative variables & Mean & Std. D \\
\hline 1 & Age & 13 & 2 \\
\hline $\mathbf{N}$ & Gender & Frequency & Percent \\
\hline 1 & Male & 47 & 52.2 \\
\hline 2 & Female & 43 & 47.8 \\
\hline \multicolumn{2}{|r|}{ Total } & 90 & 100 \\
\hline $\mathbf{N}$ & Educational level & Frequency & Percent \\
\hline 1 & Primary stage & 40 & 44.4 \\
\hline 2 & middle School & 33 & 36.7 \\
\hline 3 & High school & 17 & 18.9 \\
\hline \multicolumn{2}{|r|}{ Total } & 90 & 100 \\
\hline $\mathbf{N}$ & Orphan Type & Frequency & Percent \\
\hline 1 & \multirow{2}{*}{$\begin{array}{l}\text { orphan } \\
\text { Mother orphan }\end{array}$} & 32 & 35.6 \\
\hline 2 & & 20 & 22.2 \\
\hline 3 & \multirow{2}{*}{$\begin{array}{r}\text { Parents are orphaned together } \\
\text { Total }\end{array}$} & 38 & 42.2 \\
\hline & & 90 & 100 \\
\hline
\end{tabular}

Table No (5) shows that:

- The normal period of mechanized stranded children is (13) years, with a standard deviation of roughly two years. This may mirror the need of these children for care and consideration because of the idea of the age and the cultural conditions where they live.

- The biggest level of children with motor disabilities is male (52.2\%), while females $(47.8 \%)$. This may mirror the need of differentiating social government assistance programs in incapacitated consideration foundations to suit orphans with disabilities.

- The biggest level of orphans with disabilities in the essential stage is $(44.4 \%)$, trailed by the preliminary stage $(36.7 \%)$, lastly the optional stage $(18.9 \%)$. This may mirror the job of social government assistance organizations in giving all types of care to impaired stranded children, particularly instruction, since they are a critical human power in the public eye.

- The biggest level of children with motor disabilities is stranded by the two guardians, at a pace of $(42.2 \%)$, trailed by the dad's orphan 
with a pace of $(35.6 \%)$, lastly the mother orphan with a pace of $(22.2 \%)$. This may mirror the presentation of these children to numerous issues because of inability from one viewpoint and the loss of one or the two guardians then again.

(2) Basic data of the Officials :

Table No (6)

Basic data of the officials $(N=52)$

\begin{tabular}{|c|c|c|c|}
\hline $\mathbf{N}$ & Quantitative variables & Mean & Std. D \\
\hline 1 & Age & 35 & 4 \\
\hline 2 & Years of work experience & 7 & 2 \\
\hline $\mathbf{N}$ & Gender & Frequency & Percent \\
\hline 1 & Male & 29 & 55.8 \\
\hline 2 & Female & 23 & 44.2 \\
\hline \multicolumn{2}{|r|}{ Total } & 52 & 100 \\
\hline $\mathbf{N}$ & Qualification & Frequency & Percent \\
\hline 1 & Middle Certification & 18 & 34.6 \\
\hline 2 & Qualification above average & 8 & 15.4 \\
\hline 3 & bachelors degree & 17 & 32.7 \\
\hline 4 & Postgraduate Diploma & 9 & 17.3 \\
\hline \multicolumn{2}{|r|}{ Total } & 52 & 100 \\
\hline $\mathbf{N}$ & Career & Frequency & Percent \\
\hline 1 & Member of the Board of Directors & 12 & 23.1 \\
\hline 2 & Cashier & 4 & 7.7 \\
\hline 3 & Executive Director & 4 & 7.7 \\
\hline 4 & Program and projects officer & 6 & 11.5 \\
\hline 5 & Social worker & 9 & 17.3 \\
\hline 6 & Administrative & 10 & 19.2 \\
\hline 7 & Alternative mother & 7 & 13.5 \\
\hline & Total & 52 & 100 \\
\hline
\end{tabular}

Table No (6) shows that:

- The mean of authorities age is (35) years, with a standard deviation of roughly (4) years. This might be because of the idea of the age gathering of authorities, which may assist them with helping orphans with disabilities in their social coordination.

- The normal number of long periods of work experience is (7) years, with a standard deviation of around two years. This may mirror the capacity of authorities to accomplish the procedure of community incorporation for orphans with disabilities considering their encounters.

- $\quad$ The biggest level of authorities is male (55.8\%), while females are $(44.2 \%)$. This might be because of the assorted variety of work in handicapped government assistance organizations.

- The biggest level of authorities have a moderate capability of $(34.6 \%)$, trailed by a college capability of $(32.7 \%)$, at that point a postgraduate confirmation of $(17.3 \%)$, lastly a better than expected 
capability of (15.4\%). This may mirror the higher instructive degree of authorities, which may assist them with understanding the necessities and issues of children with disabilities.

- $\quad$ The biggest level of authorities is a board individual from (23.1\%), trailed by an executive with (19.2\%), at that point a social specialist $(17.3 \%)$, trailed by a proxy mother $(13.5 \%)$, at that point a program and undertakings official with (11.5\%), Finally, the financial officer and CEO (7.7\%). This may mirror the assorted variety of employments in impaired consideration establishments, which adds to the arrangement of social government assistance administrations for incapacitated stranded offspring of the most elevated conceivable quality.

The second axis: the dimensions of community integration for orphans with disabilities in motion:

(1) Availability of human relationships:

Table No (7)

Explains the availability of human relationships

\begin{tabular}{|c|c|c|c|c|c|c|c|}
\hline \multirow[t]{2}{*}{$\mathbf{N}$} & \multirow[t]{2}{*}{ The Phrases } & \multicolumn{3}{|c|}{$\begin{array}{l}\text { Physically disabled } \\
\text { children }(n=90)\end{array}$} & \multicolumn{3}{|c|}{$\begin{array}{l}\text { Officials } \\
(\mathrm{n}=52)\end{array}$} \\
\hline & & Mean & Std. D & Arrange & Mean & $\begin{array}{c}\text { Std. } \\
\text { D }\end{array}$ & $\begin{array}{c}\text { Arrang } \\
\text { e }\end{array}$ \\
\hline 1 & $\begin{array}{l}\text { Love and acceptance are available between children } \\
\text { and workers within the organization }\end{array}$ & 2.53 & 0.71 & 1 & 2.71 & 0.57 & 1 \\
\hline 2 & $\begin{array}{l}\text { The enterprise's atmosphere is characterized by } \\
\text { cooperation and trust between each other's children } \\
\text { during their activities }\end{array}$ & 2.36 & 0.66 & 3 & 2.54 & 0.61 & 2 \\
\hline 3 & $\begin{array}{l}\text { The spirit of participation and cooperative action } \\
\text { prevails among officials within the institution }\end{array}$ & 2.4 & 0.75 & 2 & 2.33 & 0.65 & 3 \\
\hline 4 & $\begin{array}{l}\text { There is a good relationship between the social worker } \\
\text { and the staff within the organization }\end{array}$ & 2.12 & 0.75 & 4 & 2.25 & 0.71 & 4 \\
\hline 5 & $\begin{array}{l}\text { The Foundation's employees sympathize with children } \\
\text { in different situations }\end{array}$ & 2.09 & 0.76 & 5 & 2.21 & 0.82 & 5 \\
\hline & All Variable & 2.3 & 0.38 & $\begin{array}{c}\text { M - } \\
\text { Level }\end{array}$ & 2.41 & 0.4 & $\begin{array}{c}\text { H - } \\
\text { Level }\end{array}$ \\
\hline
\end{tabular}

Table No (7) shows that:

- The degree of accessibility of human relations as dictated by the debilitated stranded children with a normal development where the math normal came to (2.3), and markers for that as indicated by the number-crunching mean course of action: In the main request there is love and acknowledgment among children and laborers inside the foundation with a number-crunching normal (2.53), and came in the second request a soul wins Participation and community oriented work among authorities inside the establishment with a normal of (2.36), lastly the representatives of the organization identify with children in various circumstances with a normal of (2.09). This may mirror the presence of a human connection between the offspring of 
one another just as among children and laborers, however authorities ought to fortify relations between these children superior to this, and this was affirmed by the aftereffects of an study(Muhammad, 2002).

- The degree of accessibility of human relations as controlled by the authorities is high, as the number juggling normal came to (2.41), and markers of that as indicated by the math mean numbercrunching: came in the primary game plan: there is love and acknowledgment among children and laborers inside the organization with a number-crunching normal (2.71), and the second positioned is described by the establishment's environment of participation and trust Between children one another while doing exercises with a number-crunching normal (2.54), lastly the representatives of the foundation feel for children in various circumstances with a number-crunching mean (2.21). This may mirror the need of authorities' anxiety to give a superior degree of human connection between stranded children with disabilities, and this was affirmed by the aftereffects of an study(AbuZayd, 2012).

(2) A change in the behavior of disabled orphaned children:

Table No (8)

The change in the behavior of children with motor disabilities

\begin{tabular}{|c|c|c|c|c|c|c|c|}
\hline \multirow[t]{2}{*}{$\mathbf{N}$} & \multirow[t]{2}{*}{ The Phrases } & \multicolumn{3}{|c|}{$\begin{array}{l}\text { Physically disabled } \\
\text { children }(n=90)\end{array}$} & \multicolumn{3}{|c|}{$\begin{array}{l}\text { Officials } \\
(\mathrm{n}=52)\end{array}$} \\
\hline & & Mean & Std. D & Arrange & Mean & $\begin{array}{c}\text { Std. } \\
\text { D }\end{array}$ & $\begin{array}{c}\text { Arrang } \\
\text { e }\end{array}$ \\
\hline 1 & $\begin{array}{l}\text { Children from the institution acquire skills that } \\
\text { change their behavior for the better }\end{array}$ & 2.03 & 0.79 & 5 & 2.02 & 0.78 & 2 \\
\hline 2 & Children's behavior can be changed & 2.18 & $\mathbf{0 . 8 2}$ & 1 & 1.81 & 0.82 & 4 \\
\hline 3 & Officials help children develop their personal abilities & 2.13 & 0.72 & 2 & 2.02 & 0.8 & 3 \\
\hline 4 & $\begin{array}{l}\text { Community inclusion provides a safe environment for } \\
\text { children to protect them from any dangers }\end{array}$ & 2.04 & 0.79 & 4 & 2.04 & 0.82 & 1 \\
\hline 5 & $\begin{array}{l}\text { Community inclusion of children contributes to } \\
\text { abandoning unwanted habits }\end{array}$ & 2.13 & 0.8 & 3 & 2.02 & 0.8 & 3 \\
\hline & All Variable & 2.1 & 0.32 & $\begin{array}{l}\text { M - } \\
\text { Level }\end{array}$ & 1.98 & 0.39 & $\begin{array}{l}\text { M - } \\
\text { Level }\end{array}$ \\
\hline
\end{tabular}

Table No (8) shows that:

- The level of effecting a change in the behavior of orphans with a motor impairment from their point of view is average, as the arithmetic average (2.1), and indications for that according to the arithmetic mean order: came in the first order. A change in the behavior of children can be made with an arithmetic average (2.18), and came in the second order that helps officials Children develop their personal abilities with an arithmetic average (2.13), and finally, children acquire from the institution the skills that lead to changing his behavior for the better with an average arithmetic (2.03). This may reflect the necessity of paying attention to making positive 
changes in the behavior of orphaned children better than that by developing their personal abilities that help to integrate them socially, and consistent with the results of a study (Hamzah, 2003).

- The level of effecting a change in the behavior of orphans with a motor impairment as determined by the officials is average, where the arithmetic average reached (1.98), and indicators for that according to the arithmetic mean arrangement: In the first order, community integration provides a safe environment for children to protect them from any risks with an arithmetic average (2.04), and came In the second order, children from the institution acquire the skills that lead to changing his behavior for the better with an average of (2.02), and finally a change in the behavior of children with an average of (1.81) can be made. This may reflect the need to support the Sondos Foundation officials the positive behaviors of orphaned children with mobility better than that, which contributes to integrating children socially, and this was confirmed by the results of a study (Hammam, 2016).

(3) Continuity in achieving social inclusion:

Table No (9)

Continuity in achieving community integration

\begin{tabular}{|c|c|c|c|c|c|c|c|}
\hline \multirow[t]{2}{*}{$\mathbf{N}$} & \multirow[t]{2}{*}{ The Phrases } & \multicolumn{3}{|c|}{$\begin{array}{l}\text { Physically disabled } \\
\text { children }(n=90)\end{array}$} & \multicolumn{3}{|c|}{$\begin{array}{l}\text { Officials } \\
(\mathrm{n}=52)\end{array}$} \\
\hline & & Mean & Std. D & Arrange & Mean & \begin{tabular}{c|c} 
Std. \\
D
\end{tabular} & $\begin{array}{c}\text { Arrang } \\
\text { e }\end{array}$ \\
\hline 1 & $\begin{array}{l}\text { There is a doctor inside the institution on an ongoing } \\
\text { basis to care for children }\end{array}$ & 2.01 & 0.83 & 3 & 1.9 & 0.8 & 5 \\
\hline 2 & $\begin{array}{l}\text { The Foundation provides children with meals } \\
\text { continuously }\end{array}$ & 2.12 & 0.8 & 1 & 2.56 & 0.7 & 2 \\
\hline 3 & $\begin{array}{l}\text { The foundation provides a social worker within the } \\
\text { foundation to constantly help children }\end{array}$ & 1.92 & 0.77 & 5 & 2.58 & 0.54 & 1 \\
\hline 4 & $\begin{array}{l}\text { The Foundation provides all necessary first aid when } \\
\text { children need it without delay }\end{array}$ & 1.98 & 0.78 & 4 & 2.35 & 0.65 & 3 \\
\hline 5 & $\begin{array}{l}\text { The psychologist is constantly stepping in with } \\
\text { children }\end{array}$ & 2.06 & 0.8 & 2 & 2.35 & 0.76 & 4 \\
\hline & All Variable & 2.02 & 0.34 & $\begin{array}{c}\text { M - } \\
\text { Level }\end{array}$ & 2.35 & 0.42 & $\begin{array}{c}\text { H - } \\
\text { Level }\end{array}$ \\
\hline
\end{tabular}

\section{Table No (9) shows that:}

- The degree of congruity in accomplishing social combination as controlled by the debilitated stranded children with a normal development, where the math normal came to (2.02), and pointers of that as indicated by the number juggling mean course of action: In the primary request, the establishment furnishes children with dinners constantly with a number-crunching normal (2.12), and the subsequent request quickens the pro Psychological mediation with children reliably with a normal number-crunching (2.06), lastly the organization gives a social specialist inside the foundation to help 
children reliably with a normal number-crunching (1.92). This may mirror that children need progression in accomplishing social consideration for them by the foundation, which encourages them to confront issues emerging from the inability to fulfill the organic, mental and social requirements for them so as to accomplish their social reconciliation. This is reliable with the aftereffects of an study(Imaniah; Fitria, 2018).

- The degree of coherence in accomplishing social incorporation as controlled by authorities is high, where the number juggling normal came to (2.35), and pointers for that as indicated by the numbercrunching mean course of action: In the main request the foundation gives a social expert inside the establishment to help children reliably with a math normal (2.58), and the second comes the accessibility of the organization Children have counts calories reliably with a number-crunching normal (2.56), lastly there is a specialist inside the foundation on a continuous premise to think about children with a normal number-crunching (1.9). It might mirror the need for authorities of the establishment to focus on the requirement for congruity in accomplishing community combination for children, which adds to improving the nature of their lives, and this is predictable with the consequences of an study(Fahmy, 2006).

(4) Providing a system for following up with disabled orphaned children:

Table No (10)

The provision of a system for following up with disabled orphaned children

\begin{tabular}{|c|c|c|c|c|c|c|c|}
\hline \multirow[t]{2}{*}{$\mathbf{N}$} & \multirow[t]{2}{*}{ The Phrases } & \multicolumn{3}{|c|}{$\begin{array}{l}\text { Physically disabled } \\
\text { children }(n=90)\end{array}$} & \multicolumn{3}{|c|}{$\begin{array}{l}\text { Officials } \\
(\mathrm{n}=52)\end{array}$} \\
\hline & & Mean & Std. D & Arrange & Mean & $\begin{array}{c}\text { Std. } \\
\text { D }\end{array}$ & $\begin{array}{c}\text { Arrang } \\
\text { e }\end{array}$ \\
\hline 1 & $\begin{array}{l}\text { The Foundation is concerned with monitoring the } \\
\text { disabled orphaned children periodically }\end{array}$ & 1.93 & 0.78 & 5 & 2.27 & 0.77 & 1 \\
\hline 2 & The institution has specialists to follow up on children & 2.12 & 0.79 & 1 & 2.17 & 0.79 & 5 \\
\hline 3 & $\begin{array}{l}\text { The Foundation seeks to follow children and know } \\
\text { their needs }\end{array}$ & 2.08 & 0.74 & 2 & 2.21 & $\mathbf{0 . 8 2}$ & 3 \\
\hline 4 & There are follow-up records within the organization & 2.08 & $\mathbf{0 . 8 1}$ & 3 & 2.21 & 0.78 & 2 \\
\hline 5 & $\begin{array}{l}\text { Follow-up records show data and needs for each } \\
\text { individual child }\end{array}$ & 2.03 & 0.79 & 4 & 2.21 & 0.8 & 4 \\
\hline & All Variable & 2.05 & 0.33 & $\begin{array}{c}\text { M - } \\
\text { Level }\end{array}$ & 2.22 & 0.42 & $\begin{array}{l}\text { M - } \\
\text { Level }\end{array}$ \\
\hline
\end{tabular}

Table No (10) shows that:

- The level of providing a system for following up with disabled orphan children with mobility from their point of view is average, where the arithmetic average reached (2.05), and indicators for that 
according to the arithmetic mean order: In the first order, the institution has specialists to follow up the children with an arithmetic average (2.12), and came in the second order the institution seeks to follow Children and knowing their needs with an arithmetic average (2.08), and finally the institution is concerned with monitoring periodically disabled orphan children with an arithmetic average (1.93). This may reflect the necessity of providing a good system for following up children within the institution, in order to achieve social integration for them. This is confirmed by the results of a study (Clarke. 2006).

- The level of providing a system for following up with motorized orphaned children as determined by the average officials, where the arithmetic average reached (2.22), and indicators for that according to the arithmetic mean arrangement: It came in the first order. The institution is concerned with monitoring the orphans with disabilities in the movement periodically with a mean (2.27), and it comes in the second There are follow-up records within the institution with an average of (2.21), and finally there are specialists in the institution for following up with children with an average of (2.17). This may reflect the necessity of the Foundation's concern to provide a better level for the follow-up of children with motor disabilities. This was confirmed by the results of a study (Matthe, 2005).

The third axis: the dimensions of limiting the social exclusion of children with physical disabilities:

(1) Non-social isolation:

Table No (11)

The lack of social isolation

\begin{tabular}{|c|c|c|c|c|c|c|c|}
\hline \multirow[t]{2}{*}{$\mathbf{N}$} & \multirow[t]{2}{*}{ The Phrases } & \multicolumn{3}{|c|}{$\begin{array}{l}\text { Physically disabled } \\
\text { children }(n=90)\end{array}$} & \multicolumn{3}{|c|}{$\begin{array}{c}\text { Officials } \\
(\mathrm{n}=52)\end{array}$} \\
\hline & & Mean & Std. D & Arrange & Mean & $\begin{array}{c}\text { Std. } \\
\text { D }\end{array}$ & $\begin{array}{c}\text { Arrang } \\
\mathbf{e}\end{array}$ \\
\hline 1 & The child participates in any other work that he does & 1.94 & 0.8 & 4 & 2.13 & 0.71 & 1 \\
\hline 2 & $\begin{array}{l}\text { The child sits with his friends and communicates with } \\
\text { them }\end{array}$ & 2.06 & 0.74 & 2 & 2.02 & 0.7 & 4 \\
\hline 3 & $\begin{array}{l}\text { Everyone cooperates with the child while carrying out } \\
\text { various activities }\end{array}$ & 2.07 & 0.73 & 1 & 2.13 & $\mathbf{0 . 8 2}$ & 2 \\
\hline 4 & Everyone's relationship with the child is positive & 1.99 & 0.79 & 3 & 2.12 & 0.81 & 3 \\
\hline 5 & Everyone listens to the child's complaint & 1.83 & 0.82 & 5 & 2.02 & 0.9 & 5 \\
\hline & All Variable & 1.98 & 0.33 & $\begin{array}{l}\text { M - } \\
\text { Level }\end{array}$ & 2.08 & 0.45 & $\begin{array}{l}\text { M - } \\
\text { Level }\end{array}$ \\
\hline
\end{tabular}

Table No (11) shows that:

- The degree of non-social seclusion as controlled by the crippled stranded children with a normal development, where the number juggling normal came to (1.98), and pointers for that as per the math mean course of action: It came in the principal request, everybody 
helps out the child during the activity of different exercises with a number-crunching normal (2.07), and the second comes in the child sits With his companions, he speaks with them with a normal score of (2.06), lastly everybody tunes in to the child's grievance with a normal score of (1.83). This may mirror the need of including stranded children with versatility disabilities in the different exercises in their consideration establishments while offering every clinical kind of assistance and prosthetic gadgets so as to confront all types of social prohibition, and this is reliable with the consequences of the study(Al-Rashidi, 2009).

- The degree of non-social confinement as controlled by the authorities is a normal, where the number juggling normal came to (2.08), and markers of that as indicated by the math mean: came in the principal request, the other child takes an interest in any work he performs with a normal number-crunching (2.13), and a standard deviation (0.71), and it comes in the request Second, everybody helps out the child during the activity of the different exercises with a mean (2.13), with a standard deviation (0.82), lastly everybody tunes in to the child's grievance with a normal (2.02). This may mirror the need of dealing with all the different consideration and exercises that are given to children inside social consideration foundations, which adds to confronting underestimation and social rejection, and this is predictable with the aftereffects of the study(Place; Hodge, 2001).

(2) Non-social deprivation:

Table No (12)

Social disadvantages

\begin{tabular}{|c|c|c|c|c|c|c|c|}
\hline \multirow[t]{2}{*}{$\mathbf{N}$} & \multirow[t]{2}{*}{ The Phrases } & \multicolumn{3}{|c|}{$\begin{array}{l}\text { Physically disabled } \\
\text { children }(n=90)\end{array}$} & \multicolumn{3}{|c|}{$\begin{array}{l}\text { Officials } \\
(\mathrm{n}=52)\end{array}$} \\
\hline & & Mean & Std. D & Arrange & Mean & $\begin{array}{c}\text { Std. } \\
\text { D }\end{array}$ & $\begin{array}{c}\text { Arrang } \\
\text { e }\end{array}$ \\
\hline 1 & $\begin{array}{l}\text { There are competent doctors for treating children } \\
\text { within the institution }\end{array}$ & 2.46 & 0.75 & 1 & 2.46 & 0.7 & 1 \\
\hline 2 & There is an interest among all children in the institution & 2.08 & $\mathbf{0 . 7 2}$ & 4 & 2.31 & 0.76 & 2 \\
\hline 3 & $\begin{array}{l}\text { There are modern possibilities for children's education } \\
\text { within the institution }\end{array}$ & 2.29 & 0.74 & 2 & 2.29 & 0.82 & 4 \\
\hline 4 & $\begin{array}{l}\text { Workers are interested in developing the capabilities of } \\
\text { the child within the institution }\end{array}$ & 1.89 & $\mathbf{0 . 7 7}$ & 5 & 2.12 & 0.76 & 5 \\
\hline 5 & $\begin{array}{l}\text { The Foundation is concerned with small projects that } \\
\text { suit the children's capabilities of the Foundation }\end{array}$ & 2.2 & $\mathbf{0 . 7 7}$ & 3 & 2.31 & 0.78 & 3 \\
\hline & All Variable & 2.18 & 0.46 & $\begin{array}{c}\text { M - } \\
\text { Level }\end{array}$ & 2.3 & 0.4 & $\begin{array}{c}\text { M - } \\
\text { Level } \\
\end{array}$ \\
\hline
\end{tabular}

Table No (12) shows that:

- The degree of social weakness as controlled by the incapacitated stranded children with a normal development where the number 
juggling normal came to (2.18), and pointers for that as indicated by the math mean course of action: In the primary request there are able specialists to treat children inside the foundation with a numbercrunching normal (2.46), and came in the second request there are current capacities To instruct children inside the organization with a normal of (2.29), lastly, laborers are keen on building up the abilities of the child inside the establishment with a normal of (1.89). It might mirror the enduring of socially debilitated orphan children from social hardship, which requires an assortment of projects and exercises gave by foundations to counter such hardship. This is predictable with the consequences of the study(Ashour and Fraija, 2019).

- The degree of social disservice as controlled by the authorities is a normal, where the math normal came to (2.3), and pointers of that as indicated by the number-crunching mean: According to the main request, there are skilled specialists to treat children inside the establishment with a number-crunching normal (2.46), and came in the subsequent request, there is consideration from everybody to children inside The foundation has a normal of (2.31), lastly, the laborers are keen on building up the capacities of the child inside the association with a normal of (2.12). It might mirror the need of focusing on giving all social consideration administrations to fulfill the different needs of children with motor disabilities. This is reliable with the consequences of an study(Clarke. 2006).

Table No (13)

Non-discrimination

\begin{tabular}{|c|c|c|c|c|c|c|c|}
\hline \multirow[t]{2}{*}{$\mathbf{N}$} & \multirow[t]{2}{*}{ The Phrases } & \multicolumn{3}{|c|}{$\begin{array}{l}\text { Physically disabled } \\
\text { children }(\mathrm{n}=90)\end{array}$} & \multicolumn{3}{|c|}{$\begin{array}{l}\text { Officials } \\
(\mathbf{n}=\mathbf{5 2})\end{array}$} \\
\hline & & Mean & Std. D & Arrange & Mean & $\begin{array}{c}\text { Std. } \\
\text { D }\end{array}$ & $\underset{\mathrm{e}}{\mathrm{Arrang}}$ \\
\hline 1 & $\begin{array}{l}\text { The institution shall take into account the absence of } \\
\text { discrimination between children within the institution }\end{array}$ & 2.08 & 0.81 & 4 & 2.21 & 0.64 & 3 \\
\hline 2 & $\begin{array}{l}\text { Every child can have their needs met without } \\
\text { discrimination }\end{array}$ & 2.17 & 0.77 & 1 & 2.23 & 0.76 & 2 \\
\hline 3 & $\begin{array}{l}\text { The child can obtain medical services without } \\
\text { discrimination }\end{array}$ & 2.14 & 0.77 & 3 & 2.27 & 0.72 & 1 \\
\hline 4 & $\begin{array}{l}\text { The child can access educational services without } \\
\text { discrimination }\end{array}$ & 2.06 & 0.71 & 5 & 2.21 & 0.8 & 4 \\
\hline 5 & $\begin{array}{l}\text { The child can get a job opportunity without mediation } \\
\text { after leaving the institution }\end{array}$ & 2.16 & 0.72 & 2 & 2.17 & 0.81 & 5 \\
\hline & All Variable & 2.12 & 0.35 & $\begin{array}{c}\text { M - } \\
\text { Level }\end{array}$ & 2.22 & 0.36 & $\begin{array}{c}\text { M - } \\
\text { Level }\end{array}$ \\
\hline
\end{tabular}

Table No (13) shows that:

- The degree of non-segregation as controlled by the handicapped stranded children with a normal development, where the number 
juggling normal came to (2.12), and pointers of that as per the math mean: It came in the principal request that each child can get his needs without separation with a number-crunching normal (2.17), and came in the second request that the child can To get an opening for work without intervention subsequent to leaving the foundation with a number-crunching normal (2.16), lastly the child can get instructive administrations without segregation with a normal number-crunching (2.06). This may mirror the need of not recognizing crippled stranded children inside the social consideration organizations, so as to have a superior degree of social incorporation for them and not barring them socially. This might be predictable with the aftereffects of an study((Postrzygacz; et, al, 2019.

- The degree of non-segregation as controlled by the authorities is normal, as the number juggling normal came to (2.22), and markers for that as per the number-crunching mean: It came in the main request that a child can get clinical administrations without separation with a number-crunching normal (2.27), and came in the second request that each child can jump On his needs without separation with a normal number-crunching normal (2.23), lastly the child can find a new line of work opportunity without intercession in the wake of leaving the establishment with a normal math (2.17). This may mirror the need to dispose of all types of separation to which children with motor disabilities are uncovered, through accomplishing social equity among citizenry. This is affirmed by the aftereffects of the study(Hammam, 2016).

(4) Social interaction:

Table No (14)

Social interaction

\begin{tabular}{|c|c|c|c|c|c|c|c|}
\hline \multirow[t]{2}{*}{$\mathbf{N}$} & \multirow[t]{2}{*}{ The Phrases } & \multicolumn{3}{|c|}{$\begin{array}{l}\text { Physically disabled } \\
\text { children }(n=90)\end{array}$} & \multicolumn{3}{|c|}{$\begin{array}{l}\text { Officials } \\
(\mathrm{n}=52)\end{array}$} \\
\hline & & Mean & Std. D & Arrange & Mean & $\begin{array}{c}\text { Std. } \\
\text { D }\end{array}$ & $\begin{array}{c}\text { Arrang } \\
\text { e }\end{array}$ \\
\hline 1 & $\begin{array}{l}\text { There is mutual respect between the child and officials } \\
\text { within the institution }\end{array}$ & 2.08 & 0.72 & 2 & 2.15 & 0.72 & 3 \\
\hline 2 & $\begin{array}{l}\text { The child maintains good social relations between him } \\
\text { and his friends inside the institution }\end{array}$ & 2.07 & 0.78 & 3 & 2.21 & 0.78 & 1 \\
\hline 3 & $\begin{array}{l}\text { There is an interaction between the child and his } \\
\text { friends }\end{array}$ & 2.12 & 0.67 & 1 & 2.1 & 0.72 & 5 \\
\hline 4 & $\begin{array}{l}\text { The child expresses his problems to those responsible } \\
\text { for him within the institution }\end{array}$ & 2.02 & 0.75 & 4 & 2.13 & 0.74 & 4 \\
\hline 5 & $\begin{array}{l}\text { The child can communicate with others inside the } \\
\text { institution }\end{array}$ & 1.97 & 0.74 & 5 & 2.21 & 0.8 & 2 \\
\hline & All Variable & 2.05 & 0.29 & $\begin{array}{l}\text { M - } \\
\text { Level }\end{array}$ & 2.16 & 0.38 & $\begin{array}{l}\text { M - } \\
\text { Level }\end{array}$ \\
\hline
\end{tabular}

Table No (14) shows that: 
- The degree of social communication as dictated by the incapacitated stranded children with a normal development, where the number juggling normal came to (2.05), and markers of that as indicated by the math mean course of action: came in the primary request there is a connection between the child and his companions with a numbercrunching normal (2.12), and came in the second request there is common regard between the child And authorities inside the foundation with a normal of (2.08), lastly the child can comprehend with others inside the establishment with a normal of (1.97). This may mirror the need of more noteworthy open doors for social connection for orphans with disabilities in organizations so as to address social prohibition for them. This is reliable with the consequences of an study(Hamzah, 2003).

- The degree of social connection as controlled by authorities is normal, where the number juggling normal (2.16), and markers for that as indicated by the math mean: came in the main game plan. In the subsequent request, the child can comprehend with others inside the establishment with a math normal (2.21), with a standard deviation (0.8), lastly there is a cooperation between the child and his companions with a normal number juggling (2.1). This may mirror the need to configuration projects and exercises in care organizations to build the social cooperation of children with disabilities. This is reliable with the consequences of an study(Clarke. 2006).

The fourth axis: the difficulties that face social integration to reduce the social exclusion of children with disabilities in orphans:

Table No (15)

Difficulties of community inclusion to reduce the social exclusion of children with disabilities

\begin{tabular}{|c|c|c|c|c|c|c|c|}
\hline \multirow[t]{2}{*}{$\mathbf{N}$} & \multirow[t]{2}{*}{ The Phrases } & \multicolumn{3}{|c|}{$\begin{array}{l}\text { Physically disabled } \\
\text { children }(n=90)\end{array}$} & \multicolumn{3}{|c|}{$\begin{array}{l}\text { Officials } \\
(\mathrm{n}=52)\end{array}$} \\
\hline & & Mean & Std. D & Arrange & Mean & $\begin{array}{c}\text { Std. } \\
\text { D }\end{array}$ & $\begin{array}{c}\text { Arrang } \\
\text { e }\end{array}$ \\
\hline 1 & $\begin{array}{l}\text { The small number of community integration } \\
\text { organizations for handicapped orphaned children }\end{array}$ & 2.46 & 0.71 & 1 & 2.46 & 0.75 & 1 \\
\hline 2 & $\begin{array}{l}\text { The large costs involved in the social integration of } \\
\text { orphaned children }\end{array}$ & 2.23 & 0.67 & 2 & 2.37 & 0.69 & 2 \\
\hline 3 & $\begin{array}{l}\text { Lack of experience of officials within the institution } \\
\text { dealing with disabled orphan children }\end{array}$ & 2.23 & 0.74 & 3 & 2.33 & 0.71 & 3 \\
\hline 4 & $\begin{array}{l}\text { The lack of an appropriate external environment to } \\
\text { deal with them humanely }\end{array}$ & 2.13 & 0.74 & 4 & 2.02 & 0.64 & 4 \\
\hline 5 & $\begin{array}{l}\text { Ineffective traditional methods in the process of social } \\
\text { inclusion }\end{array}$ & 2.13 & 0.77 & 5 & 1.98 & 0.75 & 5 \\
\hline 6 & $\begin{array}{l}\text { Community members do not accept the idea of } \\
\text { community inclusion for orphans with disabilities }\end{array}$ & 2.06 & 0.81 & 6 & 1.9 & 0.85 & 6 \\
\hline & $\begin{array}{c}\text { All Variable } \\
\end{array}$ & 2.21 & 0.38 & M - & 2.18 & 0.29 & M - \\
\hline
\end{tabular}


Table No (15) shows that:

- The degree of troubles confronting cultural incorporation to lessen the social rejection of children with motor disabilities orphans from their perspective is normal, where the number-crunching normal came to (2.21), and markers for that as indicated by the numbercrunching mean request: In the primary request there was few social consideration associations for orphans with disabilities with a numerical normal (2.46), and came in the second request of the enormous costs that the social coordination process requires for orphan children with a mean of 2.23 , lastly, the absence of community individuals to acknowledge the possibility of social mix for children with physical disabilities with a normal of (2.06). This may mirror the need of confronting these troubles with the goal that the social combination of these children can be accomplished to lessen their social prohibition as a human power that can be utilized to accomplish social improvement in the public arena. This is predictable with the consequences of an study(Muhammad, 2006).

- The degree of troubles confronting cultural coordination to decrease the social rejection of children with motor disabilities vagrants, as dictated by the normal authorities, where the number-crunching normal came to (2.18), and markers for that as per the numbercrunching mean plan: In the principal request, there was few community combination associations for children with motor disabilities, with a scientific normal (2.46), and came in the second request of the enormous costs that the social joining process requires for stranded children with a mean of (2.37), lastly, the absence of community individuals to acknowledge the possibility of community mix for orphans with disabilities with a mean (1.9). This may mirror the need of fulfilling all the necessities of stranded children with physical, mental, mental and social inabilities, and this is predictable with the consequences of an study(Matthe, 2005).

Fifth Axis: Proposals for activating societal inclusion to reduce the social exclusion of children with physical disabilities.

Table No (16)

Proposals to activate societal inclusion to reduce the social exclusion of children with disabilities

\begin{tabular}{|c|c|c|c|c|c|c|c|}
\hline \multirow[t]{2}{*}{$\mathbf{N}$} & \multirow[t]{2}{*}{ The Phrases } & \multicolumn{3}{|c|}{$\begin{array}{l}\text { Physically disabled } \\
\text { children }(n=90)\end{array}$} & \multicolumn{3}{|c|}{$\begin{array}{l}\text { Officials } \\
(\mathrm{n}=52)\end{array}$} \\
\hline & & Mean & Std. D & Arrange & Mean & $\begin{array}{c}\text { Std. } \\
\text { D }\end{array}$ & $\begin{array}{l}\text { Arrang } \\
\text { e }\end{array}$ \\
\hline 1 & $\begin{array}{l}\text { Integration of experiences between institutions working in } \\
\text { the field of community integration for children }\end{array}$ & 2.39 & 0.7 & 2 & 2.56 & 0.7 & 2 \\
\hline
\end{tabular}




\begin{tabular}{|c|c|c|c|c|c|c|c|}
\hline \multirow[t]{2}{*}{$\mathbf{N}$} & \multirow[t]{2}{*}{ The Phrases } & \multicolumn{3}{|c|}{$\begin{array}{l}\text { Physically disabled } \\
\text { children }(n=90)\end{array}$} & \multicolumn{3}{|c|}{$\begin{array}{l}\text { Officials } \\
(\mathrm{n}=52)\end{array}$} \\
\hline & & Mean & Std. D & Arrange & Mean & $\begin{array}{c}\text { Std. } \\
\text { D }\end{array}$ & $\begin{array}{c}\text { Arrang } \\
\text { e }\end{array}$ \\
\hline 2 & $\begin{array}{l}\text { Enabling the institution to achieve social integration, } \\
\text { financially and humanly }\end{array}$ & 2.32 & 0.65 & 5 & 2.62 & 0.57 & 1 \\
\hline 3 & $\begin{array}{l}\text { Providing officials within the institution with different } \\
\text { experiences for the success of the community integration } \\
\text { process for children to reduce their social exclusion }\end{array}$ & 2.5 & 0.66 & 1 & 2.48 & 0.61 & 4 \\
\hline 4 & $\begin{array}{l}\text { Holding training courses for officials to activate the } \\
\text { community integration process for children }\end{array}$ & 2.36 & 0.69 & 4 & 2.54 & 0.61 & 3 \\
\hline 5 & $\begin{array}{l}\text { It provides job opportunities for disabled orphaned } \\
\text { children after leaving the institution }\end{array}$ & 2.38 & 0.68 & 3 & 2.27 & 0.69 & 6 \\
\hline 6 & $\begin{array}{l}\text { Enlightening public opinion across all media outlets about } \\
\text { the importance of community inclusion for children with } \\
\text { mobility disabilities }\end{array}$ & 2.27 & 0.8 & 6 & 2.31 & 0.7 & 5 \\
\hline & All Variable & 2.37 & 0.3 & $\begin{array}{c}\text { H - } \\
\text { Level }\end{array}$ & 2.46 & 0.32 & $\begin{array}{c}\mathrm{H}- \\
\text { Level }\end{array}$ \\
\hline
\end{tabular}

\section{Table No (16) shows that:}

- The level of proposals for activating societal inclusion to reduce the social exclusion of children with motor disabilities orphans from their point of view is high as the arithmetic average reached (2.37), and indicators for that according to the arithmetic mean arrangement: In the first order, officials within the institution were given different experiences for the success of the social integration process for children to reduce Social exclusion with an arithmetic average (2.5), and the second order came the integration of experiences between institutions working in the field of community inclusion for children with an average arithmetic (2.39), and finally enlightening public opinion across all different media on the importance of societal inclusion of children with motor disabilities with an arithmetic average (2.27). This may reflect the need to provide an opportunity to participate in all activities in the community to reduce the social exclusion of children with disabilities. This is confirmed by the results of a study (Hamzah, 2003).

- The level of proposals for activating societal inclusion to reduce the social exclusion of children with motor disabilities orphans as determined by officials is high as the arithmetic average reached (2.46), and indicators for that according to the arithmetic mean arrangement: It came in the first order enabling the institution to achieve community inclusion financially and humanly with an arithmetic average (2.62) ), And the second order came the integration of experiences between institutions working in the field of community integration for children with an arithmetic average of 
(2.56), and finally, job opportunities for orphans with disabilities are provided after leaving the institution with an arithmetic average (2.27). This may reflect the importance of achieving community integration for children with motor disabilities, in order to reduce their social exclusion in alternative care institutions. This is confirmed by the results of the study (Al-Rashidi, 2009).

The sixth axis: the study of hypotheses study:

(1) Test of the first hypothesis of the study: "It is expected that the level of societal dimensions of integration of children with motor disabilities orphans is average":

Table No (17)

Level of societal dimensions of integration of children with motor impaired orphans as a whole is illustrated

\begin{tabular}{|c|c|c|c|c|c|c|c|}
\hline \multirow[t]{2}{*}{$\mathbf{N}$} & \multirow[t]{2}{*}{ The Dimensions } & \multicolumn{3}{|c|}{$\begin{array}{l}\text { Physically disabled } \\
\text { children }(n=90)\end{array}$} & \multicolumn{3}{|c|}{$\begin{array}{l}\text { Officials } \\
(n=52)\end{array}$} \\
\hline & & Mean & Std. D & Arrange & Mean & $\begin{array}{c}\text { Std. } \\
\text { D }\end{array}$ & $\begin{array}{c}\text { Arrang } \\
\text { e }\end{array}$ \\
\hline 1 & Availability of human relationships & 2.3 & 0.38 & 1 & 2.41 & 0.4 & 1 \\
\hline 2 & $\begin{array}{l}\text { Making a difference in the behavior of orphaned } \\
\text { children with disabilities }\end{array}$ & 2.1 & $\mathbf{0 . 3 2}$ & 2 & 1.98 & 0.39 & 4 \\
\hline 3 & Continuity in achieving social inclusion & 2.02 & 0.34 & 4 & 2.35 & 0.42 & 2 \\
\hline 4 & $\begin{array}{l}\text { Provide a system for following up with disabled } \\
\text { orphaned children }\end{array}$ & 2.05 & 0.33 & 3 & 2.22 & 0.42 & 3 \\
\hline & Dimensions of societal inclusion as a whole & 2.12 & 0.2 & $\begin{array}{l}\text { M - } \\
\text { Level }\end{array}$ & 2.24 & 0.25 & $\begin{array}{c}\text { M - } \\
\text { Level }\end{array}$ \\
\hline
\end{tabular}

Table No (17) shows that:

- The level of societal dimensions of social integration of orphaned children with mobility from their point of view is average, as the arithmetic average (2.12), and indicators of that according to the arithmetic mean order: in the first order the availability of human relations with an arithmetic average (2.3) came, and in the second order a change in the behavior of orphan children Physically handicapped with an arithmetic average (2.1), then came in the third order to provide a system for following up with orphaned children with a motorized average with a mathematical average (2.05), and finally, continuity in achieving social integration with an arithmetic average (2.02). It may reflect the necessity of rehabilitating disabled orphaned children with mobility to exercise their social roles and help them to integrate into social life and integrate into the structure of society. This is confirmed by the results of the study (Hammam, 2016). This is consistent with the results of Tables (7-10).

- The level of societal dimensions of social inclusion for orphaned children with mobility as determined by the average officials, where the arithmetic average reached (2.24), and indicators for that according to the arithmetic mean arrangement: In the first order the 
availability of human relations with an arithmetic average (2.41) came, and the second ranked continuity in achieving social integration with an average Arithmetic (2.35), then came in the third order to provide a system for following up with disabled orphaned children with a mean (2.22), and finally to bring about a change in the behavior of orphans with disabilities with a mean (1.98). It may reflect the necessity of achieving social inclusion for children with motor disabilities, by strengthening ties of belonging between the individual and society and developing a sense of social responsibility. This is confirmed by the results of the study (Imaniah; Fitria, 2018). This is consistent with the results of Tables (7-10).

- Which makes us accept the first hypothesis of the study, which states, "It is expected that the level of societal dimensions of inclusion of children with physical disabilities is moderate."

(2) Test the second hypothesis of the study: "It is expected that the level of the dimensions of limiting the social exclusion of children with motor disabilities orphans is average":

Table No (18)

Level of dimensions clarifies the reduction of social exclusion of children with disabilities in motion as a whole

\begin{tabular}{|c|c|c|c|c|c|c|c|}
\hline \multirow[t]{2}{*}{$\mathbf{N}$} & \multirow[t]{2}{*}{ The Dimensions } & \multicolumn{3}{|c|}{$\begin{array}{l}\text { Physically disabled } \\
\text { children }(\mathrm{n}=90)\end{array}$} & \multicolumn{3}{|c|}{$\begin{array}{c}\text { Officials } \\
(n=52)\end{array}$} \\
\hline & & Mean & Std. D & Arrange & Mean & \begin{tabular}{|c|} 
Std. \\
D \\
\end{tabular} & $\begin{array}{c}\text { Arrang } \\
\mathrm{e}\end{array}$ \\
\hline 1 & Non-social isolation & 1.98 & 0.33 & 4 & 2.08 & 0.45 & 4 \\
\hline 2 & No social deprivation & 2.18 & 0.46 & 1 & 2.3 & 0.4 & 1 \\
\hline 3 & Non-discrimination & 2.12 & 0.35 & 2 & 2.22 & 0.36 & 2 \\
\hline 4 & Social interaction & 2.05 & 0.29 & 3 & 2.16 & 0.38 & 3 \\
\hline & Dimensions of limiting social exclusion as a whole & 2.08 & 0.23 & $\begin{array}{c}\text { M - } \\
\text { Level }\end{array}$ & 2.19 & 0.29 & $\begin{array}{c}\text { M - } \\
\text { Level }\end{array}$ \\
\hline
\end{tabular}

Table No (18) shows that:

- The level of the dimensions of limiting the social exclusion of children with motor disabilities, as determined by children with high mobility orphans, where the arithmetic average reached (2.08), and the indicators for that according to the arithmetic mean order: In the first order, social deprivation with an arithmetic average (2.18) came, and the second came in the absence of Distinction with mean (2.12), then came in the third order, social interaction with mean (2.05), and finally, lack of social isolation with mean (1.98). This may reflect the need to formulate policies and develop plans to reduce the social exclusion of children with disabilities in motion to improve their quality of life. This is confirmed by the results of the 
study (Al-Rashidi, 2009). This is consistent with the results of Tables (11-14).

- The level of the dimensions of limiting the social exclusion of children with motor disabilities orphans as determined by the officials is high, as the arithmetic average reached (2.19), and the indicators for that according to the arithmetic mean order: In the first order, there was no social deprivation with an arithmetic average (2.3), and the second order was non-discrimination with an arithmetic average. (2.22), and then came in the third order, social interaction with an average of (2.166), and finally, lack of social isolation with an average of (2.08). This may reflect the necessity of finding an effective mechanism to achieve coordination and integration between governmental and private institutions working in the field of handicapped care in order to achieve the maximum benefit from those institutions to reduce the social exclusion of the handicapped. This is confirmed by the results of a study ((Gijsbers \& Vrooman, 2012). This is consistent with the results of Tables (1114).

- Which makes us accept the second hypothesis of the study, which "It is expected that the level of dimensions of limiting the social exclusion of children with physical disabilities is moderate."

(3) The third hypothesis test of the study: "There is a direct, statistically significant and effective relationship between societal inclusion and the reduction of social exclusion for children with motor disabilities":

Table No (19)

Simple regression analysis of the relationship between societal inclusion and reduction of social exclusion of children with motor disabilities

\begin{tabular}{|c|c|c|c|c|c|c|c|c|c|c|}
\hline \multirow{2}{*}{$\begin{array}{c}\text { Independent } \\
\text { variable }\end{array}$} & \multirow{2}{*}{$\begin{array}{c}\text { Research } \\
\text { Community }\end{array}$} & \multirow[t]{2}{*}{$\mathbf{N}$} & \multirow{2}{*}{$\begin{array}{c}\text { Regression } \\
\text { coefficient } \\
\text { B } \\
\end{array}$} & \multicolumn{2}{|c|}{ T-Test } & \multicolumn{2}{|c|}{ F-Test } & \multicolumn{2}{|c|}{$\mathbf{R}$} & \multirow[t]{2}{*}{$\mathbf{R}^{2}$} \\
\hline & & & & $\begin{array}{c}\text { Valu } \\
\text { e }\end{array}$ & Sig & Value & Sig & Value & Sig & \\
\hline \multirow{2}{*}{$\begin{array}{l}\text { Dimensions of } \\
\text { societal inclusion } \\
\text { as a whole }\end{array}$} & children & 90 & 0.326 & 5.59 & $\begin{array}{c}0.00 \\
0\end{array}$ & $\begin{array}{c}31.24 \\
5\end{array}$ & $\begin{array}{c}0.00 \\
0\end{array}$ & $\begin{array}{c}0.51 \\
2\end{array}$ & $\begin{array}{c}0.00 \\
0\end{array}$ & 0.262 \\
\hline & The officials & 52 & 0.495 & $\begin{array}{c}3.36 \\
6\end{array}$ & $\begin{array}{c}0.00 \\
0\end{array}$ & $\begin{array}{c}11.32 \\
8\end{array}$ & $\begin{array}{c}0.00 \\
0\end{array}$ & 0.43 & $\begin{array}{c}0.00 \\
0\end{array}$ & 0.185 \\
\hline
\end{tabular}

Table No (19) shows that:

- Analyzing the simple regression of the relationship between societal inclusion and limiting the social exclusion of children with motor disabilities, as defined by children with motor disabilities:

- The value of the correlation coefficient between the independent variable "dimensions of societal inclusion as a whole" and the 
dependent variable "dimensions of limiting the social exclusion of children with mobility impaired orphans as a whole" as defined by children with motor disabilities orphans (0.512), which is statistically significant at the level of significance (0.01), and indicates A direct correlation between the two variables.

- $\quad$ The result of the test $(\mathrm{F})(\mathrm{F}=31.245, \mathrm{Sig}=0.000)$ indicates the significance of the regression model, and the value of the determination coefficient reached (0.262), i.e. that societal inclusion as a whole explains $(26.2 \%)$ of the changes in limiting the social exclusion of children with motor disabilities orphans As a whole as defined by the disabled orphaned children.

- $\quad$ The value of the regression coefficient was (0.326), which indicates a direct relationship between the independent variable and the dependent variable, and the result of the $\mathrm{T}$ test $(\mathrm{T}=5.590, \mathrm{Sig}=$ 0.000 ) indicates that the effect of the independent variable on the dependent variable is a significant and statistically significant effect when Significant level (0.01).

- This may reflect the correlative relationship between societal inclusion and the reduction of social exclusion for children with motor disabilities, which requires ensuring the continuity and development of social care programs provided by disabled care institutions. This is consistent with the results of a study (Clarke. 2006). This is consistent with the results of Tables $(17,18)$.

- Which makes us accept the third hypothesis of the study, which leads to "there is a direct, significant, statistically significant relationship between societal inclusion and limiting the social exclusion of children with motor disabilities."

- Analyzing the simple regression of the relationship between social inclusion and limiting the social exclusion of children with motor disabilities, as determined by officials:

- The value of the correlation coefficient between the independent variable "the dimensions of societal inclusion as a whole" and the dependent variable "the dimensions of limiting the social exclusion of children with mobility impaired orphans as a whole" as determined by officials $(0.430)$, which is statistically significant at the level of significance (0.01), and indicates the existence of a direct correlation Between the two variables.

- $\quad$ The result of the $(\mathrm{F})$ test $(\mathrm{F}=11.328, \mathrm{Sig}=0,000)$ indicates the significance of the regression model, and the value of the determination coefficient reached $(0.185)$, that is, community integration as a whole explains (18.5\%) of the changes in the 
limitation of social exclusion of children with motor disabilities orphans A whole as defined by officials.

- The value of the regression coefficient was (0.495), which indicates a direct relationship between the independent variable and the dependent variable, and the result of the $\mathrm{T}$ test $(\mathrm{T}=3.366$, Sig $=$ 0.000 ) indicates that the effect of the independent variable on the dependent variable is a significant and statistically significant effect when Significant level (0.01).

- This may reflect the necessity of working to spread general societal awareness of the issues of the disabled, by setting an information policy aimed at influencing public opinion and changing negative attitudes towards them to achieve community integration for them. This is consistent with the results of the study (Ashour and Fraija, 2019). This is consistent with the results of Tables $(17,18)$.

- Which makes us accept the third hypothesis of the study, which leads to "there is a direct, statistically significant and effective relationship between societal inclusion and limiting the social exclusion of children with motor disabilities."

(4) The fourth hypothesis test of the study: "There are statistically significant differences statistically between the responses of the orphaned children with mobility impairments and the officials with regard to their determination of the level of societal dimensions of social inclusion of orphaned children with disabilities":

\section{Table No (20)}

Significance differences between the responses of children with motor disabilities orphans and officials regarding their determination of the level of societal dimensions of inclusion of children with motor disabilities $(\mathrm{N}=142)$

\begin{tabular}{|c|c|c|c|c|c|c|c|c|}
\hline $\mathbf{N}$ & The Dimensions & $\begin{array}{c}\text { Research } \\
\text { Community }\end{array}$ & $\mathbf{N}$ & Mean & Std. D & df & T-Test & Sig \\
\hline \multirow{2}{*}{1} & \multirow{2}{*}{ Availability of human relationships } & children & 90 & 2.3 & 0.38 & \multirow{2}{*}{140} & \multirow{2}{*}{1.597} & \multirow{2}{*}{-} \\
\hline & & The officials & 52 & 2.41 & 0.4 & & & \\
\hline \multirow[b]{2}{*}{2} & \multirow{2}{*}{$\begin{array}{l}\text { Making a difference in the behavior } \\
\text { of orphaned children with } \\
\text { disabilities }\end{array}$} & children & 90 & 2.1 & 0.32 & \multirow[b]{2}{*}{140} & \multirow[b]{2}{*}{2.062} & \multirow[b]{2}{*}{$*$} \\
\hline & & The officials & 52 & 1.98 & 0.39 & & & \\
\hline \multirow{2}{*}{3} & \multirow{2}{*}{$\begin{array}{l}\text { Continuity in achieving social } \\
\text { inclusion }\end{array}$} & children & 90 & 2.02 & 0.34 & \multirow{2}{*}{140} & \multirow{2}{*}{5.093} & \multirow{2}{*}{$* *$} \\
\hline & & The officials & 52 & 2.35 & 0.42 & & & \\
\hline \multirow{2}{*}{4} & \multirow{2}{*}{$\begin{array}{l}\text { Provide a system for following up } \\
\text { with disabled orphaned children }\end{array}$} & children & 90 & 2.05 & 0.33 & \multirow{2}{*}{140} & \multirow{2}{*}{2.624} & \multirow{2}{*}{ * } \\
\hline & & The officials & 52 & 2.22 & 0.42 & & & \\
\hline \multirow{2}{*}{\multicolumn{2}{|c|}{$\begin{array}{c}\text { Dimensions of societal inclusion as } \\
\text { a whole }\end{array}$}} & children & 90 & 2.12 & 0.2 & \multirow{2}{*}{140} & \multirow{2}{*}{3.121} & \multirow{2}{*}{$* *$} \\
\hline & & The officials & 52 & 2.24 & 0.25 & & & \\
\hline
\end{tabular}


Table No (20) shows that:

- There are significant differences statistically significant at the level of significance (0.05) between the responses of the orphaned children with mobility and officials regarding their determination of the level of change in the behavior of orphaned children with disabilities in favor of the responses of orphans with disabilities.

- There are statistically significant differences at the level of significance (0.01) and (0.05) between the responses of the orphaned children with mobility and officials regarding their determination of the level of continuity in achieving social inclusion, the level of providing a system to follow up on the orphans with disabilities, and the level of community integration dimensions of orphaned children with disabilities A whole in favor of officials' responses.

- There were no statistically significant differences between the responses of the physically disabled orphaned children and officials with regard to their determination of the level of availability of human relations.

- This may reflect the necessity of paying attention to achieving the social integration of disabled orphaned children by helping them to integrate into public life. This is consistent with the results of a study (Hamzah, 2003). This is consistent with the results of Tables (17).

- Which makes us accept the fourth hypothesis to study partially, which leads to "There are statistically significant differences statistically between the responses of the orphaned children with mobility and officials regarding their determination of the level of societal dimensions of social inclusion of orphaned children with disabilities".

(5) The fifth hypothesis test of the study: "There are statistically significant differences statistically between the responses of the orphaned children with mobility impairments and the officials with regard to their determination of the level of the dimensions of limiting the social exclusion of the orphaned children with mobility":

Table No (21)

Significance differences between the responses of children with motor disabilities orphans and officials regarding their determination of the level of dimensions of limiting the social exclusion of children with motor disabilities $(n=142)$

\begin{tabular}{|c|l|c|c|c|c|c|c|c||}
\hline N & \multicolumn{1}{|c|}{ The Dimensions } & $\begin{array}{c}\text { Research } \\
\text { Community }\end{array}$ & N & Mean & Std. D & df & T-Test & Sig \\
\hline 1 & Non-social isolation & children & 90 & 1.98 & $\mathbf{0 . 3 3}$ & $\mathbf{1 4 0}$ & $\mathbf{1 . 6 2 0}$ & - \\
\hline
\end{tabular}




\begin{tabular}{|c|c|c|c|c|c|c|c|c|}
\hline & & The officials & 52 & 2.08 & 0.45 & & & \\
\hline \multirow{2}{*}{2} & \multirow{2}{*}{ No social deprivation } & children & 90 & 2.18 & 0.46 & \multirow{2}{*}{140} & \multirow{2}{*}{1.488} & \multirow{2}{*}{-} \\
\hline & & The officials & 52 & 2.3 & 0.4 & & & \\
\hline \multirow{2}{*}{3} & \multirow{2}{*}{ Non-discrimination } & children & 90 & 2.12 & 0.35 & \multirow{2}{*}{140} & \multirow{2}{*}{1.614} & \multirow[b]{2}{*}{ - } \\
\hline & & The officials & 52 & 2.22 & 0.36 & & & \\
\hline \multirow{2}{*}{4} & \multirow{2}{*}{ Social interaction } & children & 90 & 2.05 & 0.29 & \multirow{2}{*}{140} & \multirow{2}{*}{1.947} & \multirow{2}{*}{ - } \\
\hline & & The officials & 52 & 2.16 & 0.38 & & & \\
\hline \multirow{2}{*}{\multicolumn{2}{|c|}{$\begin{array}{l}\text { Dimensions of limiting social exclusion } \\
\text { as a whole }\end{array}$}} & children & 90 & 2.08 & 0.23 & \multirow{2}{*}{140} & \multirow{2}{*}{2.458} & \multirow{2}{*}{ * } \\
\hline & & The officials & 52 & 2.19 & 0.29 & & & \\
\hline
\end{tabular}

** significant at the $(0.01)$ level

Table No (21) shows that:

(0.05) level

* significant at the

- There are statistically significant differences at the level of significance (0.05) between the responses of the orphaned children with mobility and officials regarding their determination of the level of dimensions of limiting the social exclusion of the orphaned children with mobility as a whole in favor of the officials' responses.

- There are no statistically significant differences between the responses of the orphaned children with mobility and officials regarding their determination of the level of social isolation, the level of social disadvantage, the level of non-discrimination, and the level of social interaction.

- This may reflect the necessity of encouraging disabled orphaned children with mobility to integrate into society, providing educational opportunities for them without discrimination, and formulating social welfare policies to improve the quality of their lives. This is consistent with the results of a study (Hammam, 2016). This is consistent with the results of Tables (18).

- Which makes us accept the fifth hypothesis of the study in part, which leads to "There are statistically significant differences statistically between the responses of the orphaned children with mobility and officials regarding their determination of the level of dimensions of limiting the social exclusion of children with orphans with disabilities."

\section{Eleventh: Suggested mechanisms for activating societal inclusion to reduce the social exclusion of children with physical disabilities:}

Through a review of the theoretical framework of the study and the results of the field study, a set of proposed mechanisms can be reached to activate societal inclusion to reduce the social exclusion of children with physical disabilities, as follows:

\begin{tabular}{|c|c|c|c|}
\hline $\mathbf{N}$ & Mechanisms & Performance indicators & $\begin{array}{c}\text { Suggested } \\
\text { implementati } \\
\text { on bodies }\end{array}$ \\
\hline
\end{tabular}




\begin{tabular}{|c|c|c|c|c|}
\hline $\mathbf{N}$ & Mechanisms & & Performance indicators & $\begin{array}{l}\text { Suggested } \\
\text { implementati } \\
\text { on bodies }\end{array}$ \\
\hline \multirow{5}{*}{1} & \multirow{5}{*}{$\begin{array}{l}\text { Strengtheni } \\
\text { ng social } \\
\text { welfare } \\
\text { services for } \\
\text { handicappe } \\
\text { d children }\end{array}$} & $(1-1)$ & $\begin{array}{l}\text { Estimate the societal priority needs of children with } \\
\text { disabilities }\end{array}$ & \multirow{5}{*}{$\begin{array}{l}\text { The Ministry } \\
\text { of Social } \\
\text { Solidarity } \\
\text { Handicapped } \\
\text { care } \\
\text { institutions }\end{array}$} \\
\hline & & $(1-2)$ & $\begin{array}{l}\text { Provide an accurate, up-to-date and comprehensive } \\
\text { database on children with disabilities }\end{array}$ & \\
\hline & & $(1-3)$ & $\begin{array}{l}\text { Providing the necessary resources and capabilities to } \\
\text { provide social care services for disabled children }\end{array}$ & \\
\hline & & $(1-4)$ & $\begin{array}{l}\text { Achieving partnership between the state, civil society and } \\
\text { the private sector to provide social welfare services for } \\
\text { children with disabilities }\end{array}$ & \\
\hline & & $(1-5)$ & $\begin{array}{l}\begin{array}{l}\text { Improving the quality of social care services for } \\
\text { handicapped children }\end{array} \\
\end{array}$ & \\
\hline \multirow{5}{*}{2} & \multirow{5}{*}{$\begin{array}{c}\text { Enhancing } \\
\text { the role of } \\
\text { social } \\
\text { rehabilitatio } \\
\text { n offices for } \\
\text { the disabled }\end{array}$} & $(2-1)$ & $\begin{array}{l}\text { Providing awareness and counseling programs to know } \\
\text { how to deal with the disabled }\end{array}$ & \multirow{5}{*}{$\begin{array}{c}\text { The Ministry } \\
\text { of Social } \\
\text { Solidarity } \\
\text { Social } \\
\text { rehabilitation } \\
\text { offices for the } \\
\text { disabled }\end{array}$} \\
\hline & & $(2-2)$ & $\begin{array}{l}\text { Sensitizing those who are about to get married about the } \\
\text { necessity of performing preventive medical examinations }\end{array}$ & \\
\hline & & $(2-3)$ & $\begin{array}{l}\text { Helping the handicapped to receive medical services at } \\
\text { their nearest location }\end{array}$ & \\
\hline & & $(2-4)$ & $\begin{array}{l}\text { Providing services for the disabled in a manner that } \\
\text { preserves their dignity }\end{array}$ & \\
\hline & & $(2-5)$ & $\begin{array}{l}\text { Determine the degree and type of disability to determine } \\
\text { the type of services that people with disabilities need }\end{array}$ & \\
\hline \multirow{5}{*}{3} & \multirow{5}{*}{$\begin{array}{l}\text { Strengtheni } \\
\text { ng the role } \\
\text { of } \\
\text { handicappe } \\
\text { d } \\
\text { professional } \\
\text { evaluation } \\
\text { centers }\end{array}$} & $(3-1)$ & $\begin{array}{l}\text { Conducting comprehensive medical assessments for } \\
\text { handicapped children }\end{array}$ & \multirow{5}{*}{$\begin{array}{l}\text { The Ministry } \\
\text { of Social } \\
\text { Solidarity } \\
\text { Handicapped } \\
\text { professional } \\
\text { evaluation } \\
\text { centers }\end{array}$} \\
\hline & & (3-2) & Uncover the talents and abilities of handicapped children & \\
\hline & & $(3-3)$ & $\begin{array}{l}\text { Training children with disabilities on occupations that are } \\
\text { appropriate to their abilities }\end{array}$ & \\
\hline & & (3-4) & Provide appropriate tools to train disabled children & \\
\hline & & & $\begin{array}{l}\text { Helping handicapped children to enter occupations that } \\
\text { suit their abilities after their rehabilitation and social } \\
\text { integration }\end{array}$ & \\
\hline \multirow{5}{*}{4} & \multirow{5}{*}{$\begin{array}{l}\text { Enhancing } \\
\text { the role of } \\
\text { counseling } \\
\text { and } \\
\text { psychologica } \\
\text { I counseling } \\
\text { centers for } \\
\text { the disabled }\end{array}$} & $(4-1)$ & Doing psychological scales for handicapped children & \multirow{5}{*}{$\begin{array}{l}\text { The Ministry } \\
\text { of Social } \\
\text { Solidarity } \\
\text { Centers for } \\
\text { guidance and } \\
\text { psychological } \\
\text { counseling } \\
\text { for the } \\
\text { disabled }\end{array}$} \\
\hline & & (4-2) & $\begin{array}{l}\text { Setting a psychological rehabilitation plan according to } \\
\text { the results of psychological measures for handicapped } \\
\text { children }\end{array}$ & \\
\hline & & (4-3) & $\begin{array}{l}\text { The necessity of cooperating the work team in the } \\
\text { psychological guidance and counseling centers }\end{array}$ & \\
\hline & & $(4-4)$ & $\begin{array}{l}\text { Designing programs to develop life skills for handicapped } \\
\text { children }\end{array}$ & \\
\hline & & & $\begin{array}{l}\text { Providing various aspects of psychological and social care } \\
\text { for disabled children }\end{array}$ & \\
\hline
\end{tabular}




\section{References}

\section{First: Arabic references:}

(1) Abu Al-Nasr, Mohamed Zaki (2012), Social Exclusion, The Other Side of Social Policy, Alexandria, The Modern University Office.

(2) Abu Al-Nasr, Medhat Mohamed (2004), Rehabilitation and care for the handicapped - the relationship of the handicapped to the family and society from the perspective of prevention and treatment with cases from Egypt, Saudi Arabia, Emirates, Kuwait, Oman, Yemen, Bahrain, Cairo, Itrac for printing.

(3) Abu Zaid, Safinaz Muhammed (2012), Estimating the Needs of Disabled Persons in Orphan Care Institutions, Cairo, The twenty-fifth scientific conference, Cairo, Helwan University, Faculty of Social Work, Part 3.

(4) Al-Azhari, Mona Ahmed; Abu Hashima, Mona Sameh (2010), Physical Education and Motor Disability for People with Special Needs, Cairo, The Anglo-Egyptian Library.

(5) Imam, Yusef Hashem (2002), Activating the Role of Associations to Include People with Special Needs of Disabled Persons in Society, The Eighth National Conference of the Federation, Union of the Special Class Care Authority, No. 72.

(6) Badawi, Ahmed Zaki (1987), Dictionary of Care and Social Development Terminology, Cairo, Dar Al-Kitab Al-Masry.

(7) Al-Bawadi, Hassanein Al-Muhammadi (2005), Children's Rights between Islamic Sharia and International Law, Alexandria, Dar Al-Fakr Al-Jami'a.

(8) Turki, Nashwa Ibrahim (2015), Inclusion: Its Elements - Its Objectives Types, Cairo, The Arab Foundation for Scientific Consultation and Human Resources Development, Education World Magazine, No. 52.

(9) El-Gohary, Mohamed (2008), Social Exclusion in Forms and Forms, Cairo, National Center for Social and Criminal Research, working paper presented for the tenth annual conference entitled (Social Policy and Social Justice Achievement) from May 26-29.

(10) Hassan, Abdel-Hayy Mahmoud (2002), Challenges with Disabilities from the Perspective of Social Work, Alexandria, Dar Al-Maarefa Al-Jamiiah.

(11) Hamza, Ahmed Ibrahim (2003), Constraints of integrating the handicapped in general education schools towards planning indicators to confront them, Cairo, The sixteenth scientific conference, College of Social Work, Helwan University, volume 4.

(12) Darwish, Khalil; Masoud, Wael (2009), Introduction to Social Work, Cairo, United Arab Company for Marketing and Supplies.

(13) Al-Rashidi, Abdel-Wanis Mohamed (2009), Social Planning Requirements to Face the Social Exclusion of Persons with Disabilities as an Approach to Improving Their Quality of Life, Cairo, Journal of Studies in Social Work and Humanities, Faculty of Social Work, Helwan University, C5, p 27.

(14) Al-Srouji, Talaat Mostafa (2004), Social Policy in the Framework of New Global Variables, Cairo, Dar Al-Fikr Al-Arabi.

(15) Al-Sukkari, Ahmed Shafiq (2000), Dictionary of Social Work and Social Services, Alexandria, Dar Al-Marefa Al-Jami'a. 
(16) Suleiman, Abdel Rahman Sayed (2004), Dictionary of Mental Retardation, Cairo, Zahraa Al-Sharq Library.

(17) Saleh, Abdel-Mohi Mahmoud Hassan (2003), Challenges with Disabilities from the Perspective of Social Work, Alexandria, Dar Al-Maarefa AlJamiiah.

(18) Ashour, Badra; Freija Ahmed (2019), Forms of Social Exclusion - Theoretical Study, Algeria, University of Mohamed Khidr Biskra - Faculty of Humanities and Social Sciences, Journal of Human and Social Sciences, Volume 8, No 2.

(19) Fahmy, Manal Abdel Sattar (2006), community inclusion and improving the quality of life for the mentally disabled, a study applied to government schools in the Directorate of Education in Giza Governorate, Cairo, the eighteenth scientific conference, College of Social Work, Helwan University, Volume 1.

(20) Muhammad, Adel Abdullah, (2002), autistic children, diagnostic and programmatic studies, Cairo, Dar Al Rashad.

(21) Muhammad, Abdul Hamid Muhammad (2006), The relationship between the practice of individual collective service and the mitigation of social problems of an orphan child, Journal of Studies in Social Work and Humanities, Helwan University, College of Social Work, No. (21), c 2.

(22) Melegy, Amal Abdel Samie (2003), Adolescent Children at Risk, Cairo, The Anglo-Egyptian Library.

(23) Hammam, Karim Hassan (2016), The effectiveness of the programs of civil government institutions in the social integration of children with educational difficulties, Cairo, Journal of Social Work, Egyptian Society of Social Workers, No. 55.

\section{Second: Foreign references:}

(24) Arthurson, Kathy; Jacobs, Keith (2003), Social exclusion and housing Australian Housing and Urban Research Institute, Southern Research Centre, AHURI Final Report No. 51.

(25) Clarke, Harriet (2006), Preventing Social Exclusion of Disabled Children and Their Families, Literature review paper produced for the National Evaluation of the Children's Fund, United Kingdom, The University of Birmingham, Institute of Applied Social Studies, Research Report No 782.

(26) Developer Space (2020), What is Physical Disability?, Geneva, the Developer Space, in www.cs.stanford.edu .

(27) Gijsbers, Gerda Jehoel; Vrooman, Cok (2012), Social Exclusion of the Elderly: A Comparative Study of EU Member States, European Network Of Economic Policy, Report Research Institutes, No. 57.

(28) Hills, John Robert; Grand, Julian Le; Piachaud, David (2014), Understanding Social Exclusion, The London School of Economics and Political Science, Center for Analysis of Social Exclusion, An ESRC Research Centre.

(29) Hodkinson, Alan (2011), Inclusion: A Defining Definition, Power and Education, Vol 3, No 2.

(30) Imaniah, Ikhfi; Fitria, Nurul (2018), Inclusive Education for Students with Disability, SHS Web of Conferences 42, EDP Sciences..

(31) Place, Kimberly ; Hodge, Samuel R. (2001), Social Inclusion of Students With Physical Disabilities in General Physical, New York University, Human Kinetics Publishers, Volume 18. 
(32) Postrzygacz, Beata Trębicka; Roguska, Agnieszka; Jaszczuk, Alicja Antas (2018), From Exclusion To Inclusion of People With Disabilities, Seville, Spain Proceedings of ICERI2018 Conference, 12th-14th November.

(33) Silver, Hilary (2015), The Contexts of Social Inclusion, Department of Economic \& Social Affairs, DESA Working Paper No. 144.

(34) Smithgall, Cheryl; Gladden, Robert Matthew; Yang, Duck-Hye; Goerge, Robert, Behavior Problems and Educational Disruptions among Children in Out-of-Home Care in Chicago. Chapin Hall Working Paper, U.S.A, ERIC, 2005.

(35) United Nations Development Programme (2006): Poverty, Unemployment and Social Exclusion, New York.

(36) World Health Organization (2010): Poverty, social exclusion and health systems in the WHO European Region, Regional Office for Europe. 
مجلة كلية الخدمة الاجتماعية للار اسات و البحوث الاجتماعية - جامعة الفيوم 